\title{
PRMT5 function and targeting in cancer
}

\author{
Hyungsoo Kim ${ }^{1, *}$ and Ze'ev A. Ronai ${ }^{1, *}$ \\ ${ }^{1}$ Cancer Center, Sanford Burnham Prebys Medical Discovery Institute, La Jolla, CA, 92037, USA. \\ * Corresponding Authors: \\ Ze'ev Ronai, SBP Medical Discovery Institute, 10901 N. Torrey Pines Rd, La Jolla, CA 92037, phone: 858-646-3185; \\ E-mail: zeev@ronailab.net \\ Hyungsoo Kim, SBP Medical Discovery Institute, 10901 N. Torrey Pines Rd, La Jolla, CA 9203; E-mail: hkim@sbpdiscovery.org
}

\begin{abstract}
Protein methyl transferases play critical roles in numerous regulatory pathways that underlie cancer development, progression and therapyresponse. Here we discuss the function of PRMT5, a member of the nine-member PRMT family, in controlling oncogenic processes including tumor intrinsic, as well as extrinsic microenvironmental signaling pathways. We discuss PRMT5 effect on histone methylation and methylation of regulatory proteins including those involved in RNA splicing, cell cycle, cell death and metabolic signaling. In all, we highlight the importance of PRMT5 regulation and function in cancer, which provide the foundation for therapeutic modalities targeting PRMT5.
\end{abstract}

doi: $10.15698 /$ cst2020.08.228

Received originally: 12.05 .2020

in revised form: 03.06.2020,

Accepted 04.06.2020,

Published 13.07.2020.

Keywords: PRMT5, PRMT1, histone, transcription, splicing, MEP50, methylation, methyltransferase.

\begin{abstract}
Abbreviatons:
aDMA - asymmetric dimethylarginine; $A M L$ - acute myeloid leukemia; $\boldsymbol{A R}$ - androgen receptor; CSC - cancer stem cell; $\mathbf{D D R}$ DNA damage response; DSB - double strand break; HCC hepatocellular carcinoma; $\boldsymbol{H R}$ - homologous recombination; ICT immune checkpoint therapy; KO - knockout; IncRNA - long noncoding RNA; me1 - monomethylation; m2a - asymmetric demethylation; $\mathbf{m 2 s}$ - symmetric demethylation; MMA monomethylarginine; MTA - methylthioadenosine; MTAP - MTA phosphorylase; PC - prostate cancer; PDGF - platelet derived growth factor; PHD - plant homeodomain; PRMT - protein arginine methyltransferase; PTM - posttranslational modification; SAM - Sadenosylmethionine; sDMA - symmetric dimethylarginine; snRNP small nuclear ribonucleoprotein particle; $T C R-T$ cell receptor; Treg - regulatory $T$ cell.
\end{abstract}

\section{INTRODUCTION}

Posttranslational modifications (PTMs) are critical for proteome diversification. Protein modification on one or multiple sites can determine its conformation, subcellular localization, interaction with other proteins, stability, and/or activity. Such PTMs are mediated by diverse enzymatic processes, among them, phosphorylation, acetylation, ubiquitination, methylation and hydroxylation, and in turn reversed by enzymes that antagonize them, such as phosphatases, deubiquitinating enzymes, deacetylases and demethylases, to name a few.

Protein methylation on arginine residue was initially reported in late 1960s and early 1970s [1-3]. The first member of the protein arginine methyltransferase (PRMT) family, PRMT1 [4] was identified in 1996, followed soon after by nine others, including PRMT5. Initially identified as a 72-kDa pICln binding protein (IBP72, [5]) or JAK-binding protein 1 (JBP1, [6]), PRMT5 shares homology with the yeast proteins Skb1 (Shk1 kinase-binding protein 1 in Schizosaccharomyces pombe) and HsI7p (histone synthetic lethal 7 in Saccharomyces cerevisiae). PRMT5 was later characterized as a distinct type of mammalian protein arginine N-methyltransferase [6-8].

Arginine-methylated proteins function in a number of key cellular processes required for maintenance of tissue homeostasis as well as diseases phenotypes. Use of both genetic (KO (knockout) mouse models) and pharmacological (small molecule inhibitors) tools has established the importance of arginine methylation in stem cell activity, development, neurodegenerative disease and cancer (reviewed in [9]). Among nine members of PRMT family, PRMT5, PRMT1 and CARM1 are most highly expressed in cancer (621 cancer cell lines from cancer cell line encyclopedia database) and such high expression is correlated with worse prognosis of patients in a number of cancer types. Accordingly, of 949 PRMT-related publications, most have focused on cancer, of which 35\% studied PRMT5, 28\% 
PRMT1, and 19\% CARM1. These three PRMTs appear to promote oncogenesis through arginine-methylationmediated control of gene expression, RNA splicing and DNA damage response (reviewed in [10]). These provide the foundation for clinical evaluation of PRMT5 (four clinical trials) and PRMT1 (one clinical trial) in cancer therapy. Here, we review current understanding of PRMT5, highlighting its role in cancer.

\section{PRMT5 STRUCTURE AND FUNCTION}

PRMT family enzymes serve as "writers" of PTM, catalyzing three distinct types of methylation. In all, a methyl (-CH3) group from the methyl donor S-adenosylmethionine (SAM or AdoMet) is transferred to a guanidinium nitrogen of arginine on a target protein, generating a methylated guanidinium moiety and S-adenosylhomocysteine (SAH or AdoHcy), which is salvaged and re-used for methionine biosynthesis. In human cells, nine PRMTs catalyze three distinct methylation reactions. Type I PRMTs, including PRMT1, 2, 3, 6, 8, and CARM1 (PRMT4), catalyze $\omega-N^{G_{-}}$ monomethylarginine (MMA) and asymmetric $\omega-N^{G}, N^{G}-$ asymmetric dimethylarginine (aDMA). The type II PRMTs PRMT5 and 9 catalyze MMA and $\omega-N^{G,} N^{G}-$ symmetric dimethylarginine (sDMA). PRMT7, a type III PRMT, catalyzes only MMA. These modifications elicit a steric effect and change hydrogen bonding interaction of the methylated side chain, in turn altering molecular characteristics and function of the modified protein.

PRMT5 forms a unique hetero-octameric complex, which is composed of four PRMT5 proteins plus four essential cofactors, MEP50 (methylosome protein 50)/WDR77 (WD repeat domain 77). The unique $\mathrm{N}$-terminal TIM barrel structure of the PRMT5 monomer enables formation of PRMT5 tetramer at the center of octameric complex and subsequent decoration of the PRMT5 tetramer with four MEP50 molecules $[11,12]$. The PRMT5/MEP50 complex exhibits higher affinity to SAM and to the target substrate relative to a PRMT5 homodimer, resulting in a higher methylation activity of the hetero-octameric PRMT5/MEP50 complex [11].

The C-terminal catalytic domain of PRMT5 consists of two domains, the Rossam fold and $\beta$-barrel domains, required for binding cofactor (the methyl donor, SAM/AdoMet) and substrate, respectively. The structural restraints of substrate binding dictate preferential methylation of glycine-rich sequences, which allow conformational freedom of polypeptide chain to form a sharp $\beta$-turn [11] Indeed, extensive proteomic analysis of immuno-enriched arginine methylation sites for PRMT5 indicates a preference for arginine flanked by glycines (at -1 and +1 ; e.g., GRG) rather than other amino acids within substrate peptides $[13,14]$.

\section{PRMT5 IN DEVELOPMENT, TISSUE HOMEOSTASIS AND CANCER}

PRMT5 methylation of proteins is implicated in control of normal and pathological conditions, among them development, tissue homeostasis and cancer. Global PRMT5 KO in mice results in embryonic lethality [15], indicative of a developmental role. Conditional PRMT5 KO in specific tissues has allowed analysis of PRMT5 function in maintenance of tissue homeostasis, and survival and selfrenewing capacity of stem/progenitor cells in nervous, muscular, hematopoietic and reproductive systems [9]. Here, we discuss PRMT5 function in the context of cancerrelated activities.

\section{PRMT5 activity in tumor autonomous functions}

PRMT5 plays a complex role in oncogenesis, as it is known to control expression of genes implicated in both tumor promotion and suppression (Table 1). The intrinsic roles of PRMT5 in cancer could be marked by altered expression of PRMT5 or of its adaptor proteins or by altered availability of factors that control its catalytic activity. Such deregulation of PRMT5 catalytic activity is often reflected by arginine methylation of target proteins functioning in either epigenetic regulation of gene expression, splicing, or signal transduction.

PRMT5 control of gene expression by histone methylation Arginine methylation of histone tails is an epigenetic modification catalyzed by PRMT writers that controls gene expression. Type I or type II PRMTs introduce MMA, aDMA or sDMA to arginine residues in histone tails, enabling recruitment of specific reader(s) of those modified arginine residues, along with other chromatin remodeling modifiers. This in turn determines histone marks leading to gene activation or repression (Figure 1).

As a major type II PRMT, PRMT5 catalyzes methylation of four arginine residues within histone tails, namely, H4R3, H2AR3, H3R8 and H3R2 $[6,8]$. Of those, H4R3me2s and H3R8me2s are generally associated with transcriptional repression. PRMT5 in association with components of the SWI/SNF chromatin remodeling complex (e.g., BRG-1, BRM, or BRD7) catalyzes histone methylations implicated in repression of the tumor suppressor genes ST7, NM23, RB1, RBL1 and RBL2 [16-19]. Direct interaction of PRMT5 with the MEN1 tumor suppressor in pancreatic islet tumors reportedly increases repressive sDMAs on $\mathrm{H} 4$ (H4R3me2s) and suppresses Gas1, PTCH1 and c-myc expression, thereby limiting oncogenic SHH (sonic hedgehog) signaling in these tumors. Notably, MEN1 mutations, which are frequently seen in inherited tumor syndromes, relieve repression by PRMT5, enabling oncogenic signaling and tumor growth $[20,21]$.

High PRMT5 expression in human cancers is implicated in tumor promotion through histone tail modifications that repress miRNAs that target tumor promoting genes. For example, in B cell lymphoma PRMT5 activity increases expression of cyclin D1 and c-myc in tumor cells by repressing miR-33b, miR-96 and miR-503. In lung cancer, PRMT5 activity increases FGFR3 expression by repressing miR-99, and in AML (acute myeloid leukemia) PRMT5 repression of miR29b upregulates FLT3 [22-24]. 
TABLE 1. Summary of PRMT5 substrates and the biological effect of their methylation by PRMT5.

\begin{tabular}{|c|c|c|c|c|c|c|}
\hline & Substrate & Effect of methylation & $\begin{array}{c}\text { Targets / } \\
\text { Biological outcome }\end{array}$ & $\begin{array}{l}\text { Oncogen- } \\
\text { ic/TS* }\end{array}$ & $\begin{array}{l}\text { Refer- } \\
\text { ences }\end{array}$ & Cancer type \\
\hline \multirow{7}{*}{$\begin{array}{l}\tilde{y} \\
\stackrel{c}{0} \\
\stackrel{\underline{n}}{x}\end{array}$} & H3R8, H4R3 & Transcription repression & ST7, NM23, RB1, RBL1, RBL2, CDH1 & Oncogenic & $\begin{array}{l}\text { [17-19, } \\
29]\end{array}$ & $\begin{array}{l}\text { Leukemia, lymphoma, breast } \\
\text { cancer }\end{array}$ \\
\hline & H4R3 & Transcription repression & Gas1, PTCH1, c-Myc & TS & {$[20,21]$} & Pancreatic islet tumor \\
\hline & H3R8, H4R3 & Transcription repression & $\begin{array}{l}\text { miRNAs targeting cyclinD1, c-Myc, FGFR3, } \\
\text { FLT3 }\end{array}$ & Oncogenic & {$[22-24]$} & $\begin{array}{l}\text { Lymphoma, lung cancer, } \\
\text { leukemia }\end{array}$ \\
\hline & H3R8, H4R3 & Transcription repression & Cul4A/B & Oncogenic & {$[67]$} & Lymphoma \\
\hline & H3R8, H4R3 & Transcription activation & elF4E, FGFR3, AR & Oncogenic & {$[25,26]$} & Colon cancer, prostate Cancer \\
\hline & H3R2 & Transcription activation & VIM, FOXP1, SLC7A11, RNF168 & Oncogenic & $\begin{array}{l}{[38-40} \\
88,134]\end{array}$ & Lung Cancer, breast cancer \\
\hline & H4R3 & Gene silencing & DNMT3A & ND & {$[31]$} & \\
\hline \multirow{9}{*}{ 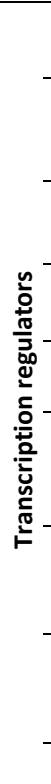 } & TP53 & Transcription activation & $\begin{array}{l}\text { Transcription activation/ cell cycle arrest, } \\
\text { apoptosis }\end{array}$ & TS & {$[41,42]$} & Sarcoma, lymphoma \\
\hline & E2F1 & Decrease protein half-life & $\begin{array}{l}\text { Decrease protein half-life/ promote growth } \\
\text { or inhibit apoptosis }\end{array}$ & Oncogenic & [43] & Colon cancer \\
\hline & RelA/p65 & Enhance DNA binding & Enhance DNA binding/ Activates NF-?B & Oncogenic & {$[45]$} & \\
\hline & KLF4 & Increase protein half-life & Increase p21/Cip1, repress BAX & Oncogenic & {$[48]$} & Breast cancer \\
\hline & SREBP1 & Increase protein half-life & Increase protein half-life/ lipogenesis & Oncogenic & [49] & Hepatocellular carcinoma \\
\hline & $\begin{array}{l}\text { Androgen } \\
\text { Receptor }\end{array}$ & $\begin{array}{l}\text { Repress recruitment to } \\
\text { target promoter }\end{array}$ & $\begin{array}{l}\text { Repress recruitment to target promoter/ } \\
\text { repress AR target genes }\end{array}$ & Oncogenic & {$[51]$} & $\begin{array}{l}\text { TMPRSS2:ERG positive pro- } \\
\text { state cancer }\end{array}$ \\
\hline & SKI & $\begin{array}{l}\text { Repress recruitment to } \\
\text { target promoter }\end{array}$ & $\begin{array}{l}\text { Repress recruitment to target promoter/ } \\
\text { Activates SKI target genes; SOX10, PAX3 }\end{array}$ & Oncogenic & {$[53]$} & Melanoma \\
\hline & BCL6 & Enhance repressor activity & $\begin{array}{l}\text { Enhance repressor activity/ Repress BCL6 } \\
\text { target genes }\end{array}$ & Oncogenic & {$[52]$} & Lymphoma \\
\hline & FOXP3 & Enhance activity & Enhance Treg function & Oncogenic & {$[103]$} & Regulatory $\mathrm{T}$ cell \\
\hline \multirow{3}{*}{ 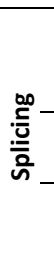 } & $\begin{array}{l}\text { SmB/B', } \\
\text { SmD1, } \\
\text { SmD3 }\end{array}$ & SnRNP assembly & Intact splicing & & $\begin{array}{l}{[59,122,} \\
123]\end{array}$ & \\
\hline & SRSF1 & mRNA and protein binding & Intact splicing pattern & Oncogenic & {$[57]$} & AML \\
\hline & ZNF326 & $\begin{array}{l}\text { Loss of activity in alterna- } \\
\text { tive splicing }\end{array}$ & $\begin{array}{l}\text { Inclusion of } \mathrm{A}-\mathrm{T} \text { rich exons coupled mRNA } \\
\text { decay }\end{array}$ & Oncogenic & {$[135]$} & Breast Cancer \\
\hline \multirow{3}{*}{ 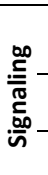 } & EGFR & $\begin{array}{l}\text { Enhance EGFR-SHP1 inter- } \\
\text { action }\end{array}$ & Repress ERK activation & TS & [80] & Breast Cancer \\
\hline & CRAF & Decrease protein half-life & Repress ERK activation & TS & [81] & Pheochromocytoma \\
\hline & PDGFR & Increase protein half-life & Activates Akt/ERK signaling & Oncogenic & {$[82]$} & Oligodendrocyte \\
\hline \multirow{4}{*}{ 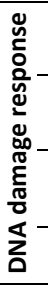 } & RUVBL1 & Activate TIP60 & Enhance homologous recombination & ND & {$[91]$} & \\
\hline & TDP1 & Enhance activity & Repair DNA damage caused by Top1cc & ND & {$[92]$} & \\
\hline & FEN1 & $\begin{array}{l}\text { Enhance recruitment to } \\
\text { replication/repair foci }\end{array}$ & Intact replication and repair & ND & [89] & \\
\hline & RAD9 & Enhance activity & Intact cell cycle checkpoint & ND & {$[90]$} & \\
\hline \multirow{3}{*}{$\begin{array}{l}\frac{n}{d} \\
\frac{a}{0} \\
0\end{array}$} & PDCD4 & Modify function & Enhance viability and growth & Oncogenic & $\begin{array}{l}{[136,} \\
137]\end{array}$ & Breast Cancer \\
\hline & IFI16 & Inhibit activity & Repress STING activation & Oncogenic & [93] & Melanoma \\
\hline & TRIM21 & Inhibit E3 ligase activity & Inhibit IKKb degradation & Oncogenic & [84] & Multiple myeloma \\
\hline
\end{tabular}

"TS*" and "ND" indicate "Tumor suppressive" and "not determined", respectively. 
While H3R8me2s and H4R3me2s are largely considered repressive marks, they are also implicated in transcriptional activation of some genes, as has been shown for FGFR3 and elF4E expression in colorectal cancers [25], and AR (androgen receptor) expression in prostate cancers [26]. Indeed, PRMT5 depletion or inhibition downregulates roughly $50 \%$ of genes that exhibit 2 -fold change $(\sim 1,300$ genes) in AML, of which 53\% (335 genes) restored expression upon inhibition of the H3K27 methyltransferase, EZH2. Further, H3K27me3 at the transcription start site of $25 \%$ of the 335 genes was reversed upon EZH2 inhibition [27]. These findings further highlight PRMT5-dependent regulation of gene expression. Notably, growing evidence support a crosstalk between different types of histone modification pointing to a complex, non-linear regulation. Accordingly, H3R8me2s results in deacetylation of H3K9 as a repressive mark [17], and H4R3me2s is associated with H4K5 acetylation as an active expression mark [28]. Thus, dynamic crosstalk between histone modifiers could serve as context-dependent histone marks influencing active/repressive gene expression.

H4R3 methylation by PRMT5 (H4R3me2s) was also linked with gene repression, through histone ubiquitination or DNA methylation. PRMT5 methylation of H4R3me2s results in its interaction with PHF1 (plant homeodomain (PHD) finger protein-1) through the $\mathrm{N}$-terminal PHD domain, while its second PHD motif binds DDB1, a component of CRL4B-Ring E3 ligase complex. By bridging DDB1 to methylated histones PHF1 enables the monoubiquitination of H2AK119, which is essential to maintain PcG (polycomb group)-target gene repressive identity $[29,30]$. PRMT5 methylation of $\mathrm{H} 4 \mathrm{R} 3$ also recruits DNMT3A through the binding of H4R3me2s to the PHD motif in DNMT3A, there-

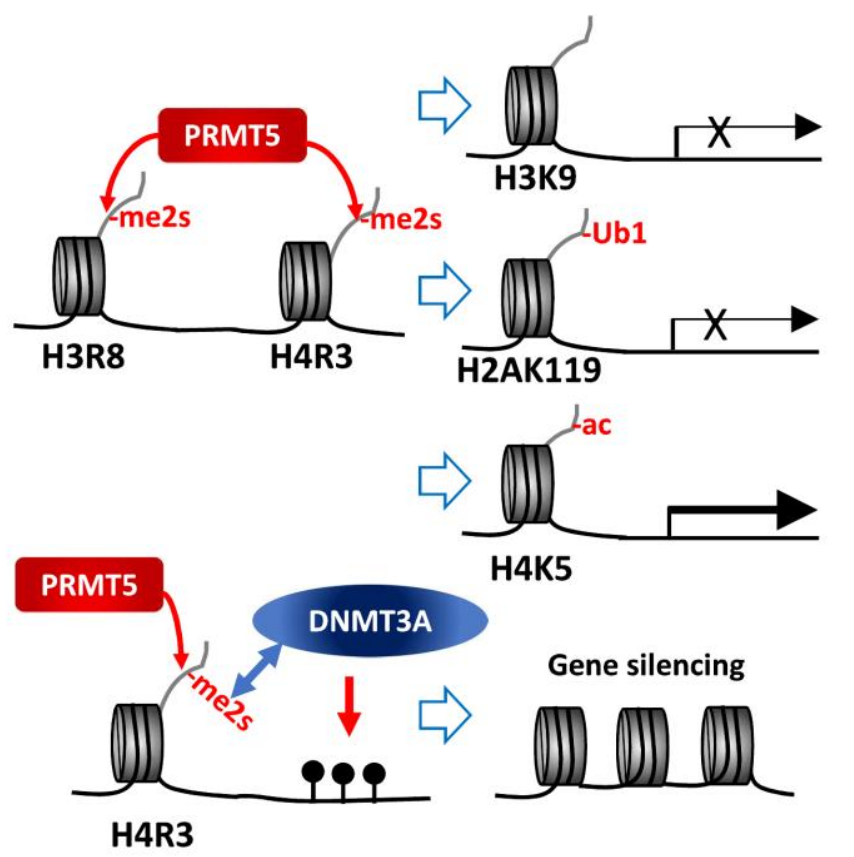

by linking repressive H4R3me2s mark to DNA methylation that functions in gene silencing [31].

In contrast, PRMT5 methylation on H3R2 is generally associated with transcriptional activation of target genes. Notably, H3R2 can be methylated by PRMT5 or PRMT6, resulting in three types of methylation, H3R2me1, H3R2me2a or H3R2me2s. H3R2me2s, catalyzed by PRMT5, recruits WDR5 (a reader with a tudor domain recognizing sDMA) along with the MLL-family coactivator complex, resulting in $\mathrm{H} 3 \mathrm{~K} 4 \mathrm{me} 3$, indicative of an active promoter, in the euchromatic loci [32-34]. On the other hand, H3R2me2a catalyzed by PRMT6 is enriched in heterochromatic or inactive euchromatic loci and is mutually exclusive with the presence of MLL-coactivator complex for H3K4me3 (Figure 1) [35-37]. Structure-based analysis of WDR5 binding to H3R2 harboring different types of arginine methylation reveals a binary switch: WDR5 binds equally to H3R2me0, me1 and me2s, but not to H3R2me2a [34]. Thus, PRMT5 methylated H3R2 (H3R2me1 or H3R2me2s) recruits WDR5/MLL complex resulting in gene activation. Along these lines, PRMT5 recruitment to the FOXP1 promoter facilitates FOXP1 expression via PRMT5dependent H3R2me2s with concomitant WDR5/SET1/MLL complex-driven $\mathrm{H} 3 \mathrm{~K} 4 \mathrm{me} 3$, implicated in maintenance of stemness in breast cancer stem cells (BCSCs) [38]. Genotoxic stress, including chemotherapy, induces interaction between $\beta$-catenin, ATM-phosphorylated JDP2 (Jun dimerization protein 2) and PRMT5, resulting in transcription of genes implicated in redox homeostasis. In this process, H3R2me1/H3R2me2s catalyzed by PRMT5 recruits the WDR5/MLL complex resulting in H3K4me3 and transcriptional activation of redox-related genes [39]. PRMT5 forms a complex with the adaptor protein SHARPIN implicated in

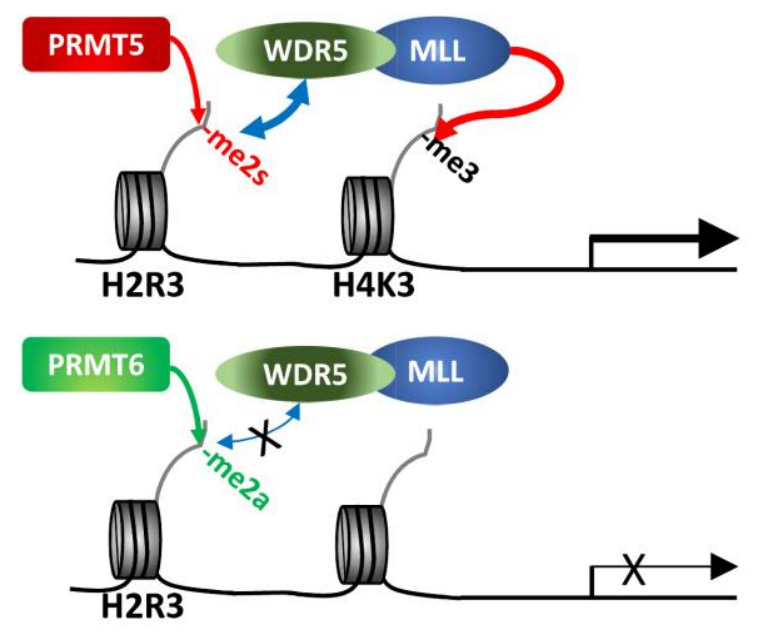

FIGURE 1: PRMT5 methylation of histone tails. PRMT5 methylation of histone tails results in activation/repression of target gene expression depending on subsequent modifications of histones or DNA. 
H3R2me1 modification and recruitment of WDR5-ASH2 (MLL-component), facilitating formation of $\mathrm{H} 3 \mathrm{~K} 4 \mathrm{me} 3$ on genes functioning in metastasis [40].

\section{PRMT5 control of gene expression by non-histone pro-} teins

Several non-histone proteins with tumor promoting or suppressing functions have been identified as PRMT5 substrates (Figure 2). STRAP, a factor recruited to the p53 complex during the DNA damage response (DDR), recruits PRMT5 and facilitates arginine methylation within the p53 oligomerization domain, decreasing p53 oligomerization which in turn increases nuclear retention of p53, with a concomitant increase in the expression of its target genes p21 and PUMA [41]. Likewise, PRMT5 methylation of p53 was implicated in altered nuclear localization and activity, which promotes lymphomagenesis [42].

An interesting example for the impact of methylation on protein function is provided by the opposing cellular functions of E2F-1, which are methylation-dependent. PRMT5 and PRMT1 methylate distinct arginine residues on E2F1 in a mutually exclusive manner, resulting in functionally opposing outcomes. The DDR induces E2F-1 methylation by PRMT1, which increases E2F-1 levels and transcriptionally activates genes implicated in promoting apoptosis. Conversely, PRMT5 methylation of E2F-1 is recognized by the tudor domain protein, p100-TSN, which decreases E2F-
1 half-life and increases cell viability. During cell cycle progression, cyclin A binding to E2F-1 masks PRMT1 methylation of E2F-1, repressing its ability to promote apoptosis $[43,44]$.

PRMT5 methylation (sDMA) of arginine 30 in the DNAbinding domain of p65/RelA, a subunit of the NF-KB transcription factor, activates NF-KB transcriptional activity via enhancing its DNA binding affinity [45]. Conversely, PRMT1 methylation (aDMA) of the same residue represses DNA binding by $p 65 /$ RelA following TNF $\alpha$ stimulation [46]. This switch highlights the importance of methylation type in defining NF-KB transcriptional outcomes. KLF4 (Kruppel-like factor 4), a zinc finger transcription factor, is methylated by PRMT5, which then blocks its ubiquitination by $\mathrm{pVHL}$ and stabilizes KLF4. Consequently, increased KLF4 availability contributes to breast cancer tumorigenesis by augmenting oncogenic signaling and expression of cell cycle genes [47, 48]. Likewise, PRMT5-methylation of SREBP1, a transcription factor required for de novo lipogenesis, prevents its phosphorylation by GSK3 $\beta$ and subsequent ubiquitination by FBXW7, thereby increasing lipogenesis and tumor growth of hepatocellular carcinoma (HCC) [49]. PRMT5 methylation of the TMPRSS2:ERG fusion protein is commonly seen in prostate cancer (PC) and implicated in prostate tumor formation by inhibiting AR -dependent transcription [50]. Mechanistically, PRMT5 interaction with the TMPRSS2:ERG fusion protein catalyzes methylation of argi-

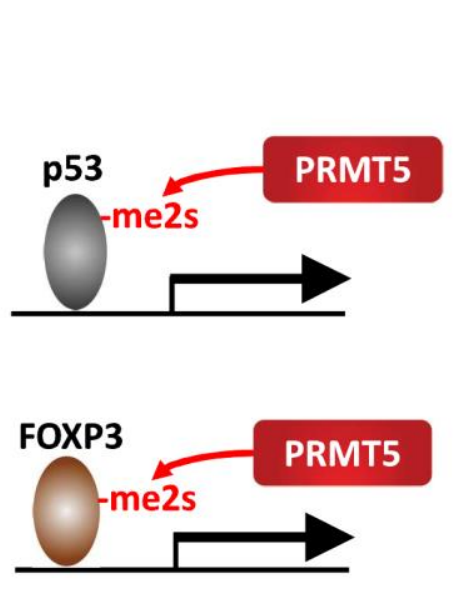

NF-KB
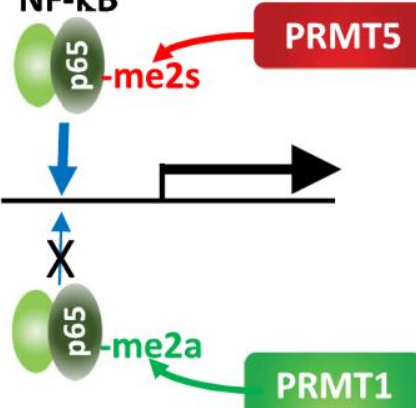

AR
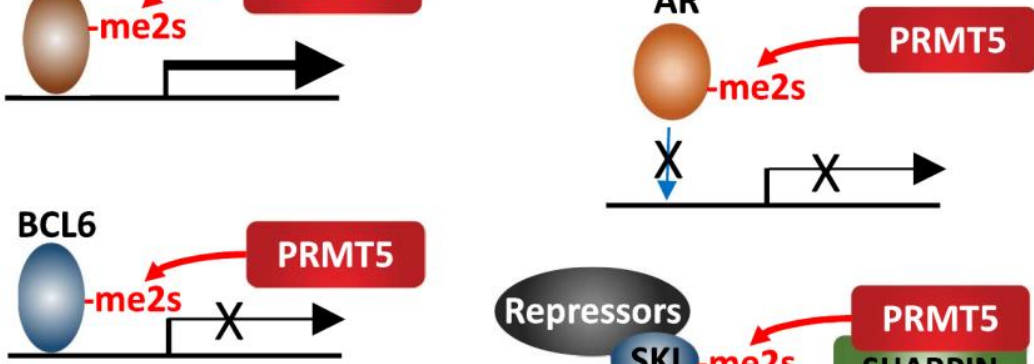
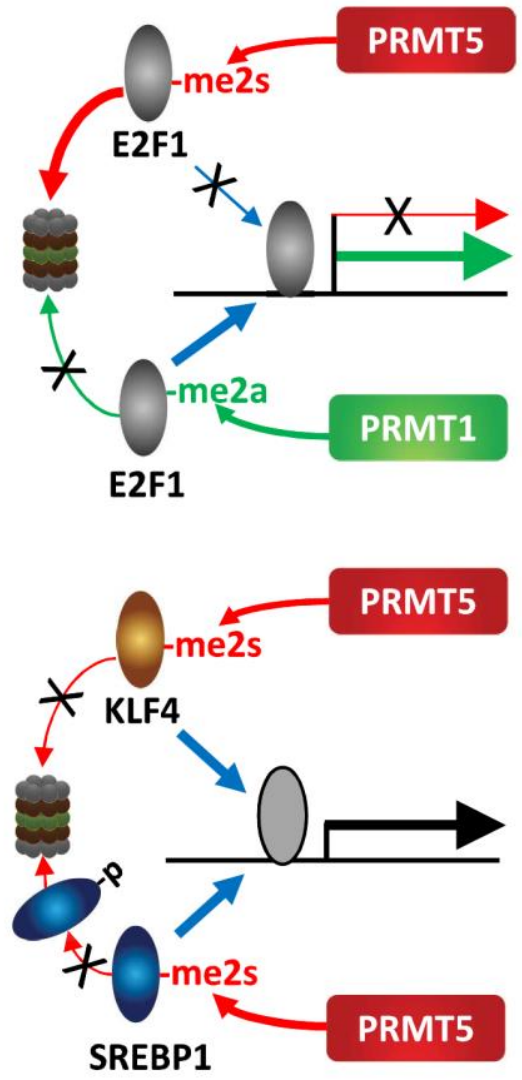

FIGURE 2: PRMT5 methylation of transcription factors. PRMT5 methylation of select transcription factors affects their activity, recruitment and stability. 
nine 761 in the AR LBD (ligand binding domain), which abrogates DNA binding, ligand-dependent $A R$ activation and expression of AR-target genes [51]. PRMT5 methylation of R305 in BCL6, a transcriptional repressor and master regulator of normal GC (germinal center) formation and GCderived B-cell lymphomagenesis, is required for its repressive activity on BCL6 target genes. Thus, PRMT5 inhibition derepresses BCL6 target genes, and suppresses DLBCL (diffuse large B-cell lymphoma) proliferation [52]. Our studies have identified SKI, a component of a transcriptional repressor complex antagonizing TGF $\beta$ signaling, as a substrate for PRMT5-MEP50-SHARPIN, which limits SKI recruitment to SOX10 and PAX3 promoters and derepresses them. In this context, PRMT5 control of SKI enhances melanoma growth by upregulating SOX10 and PAX3, which drive melanoma growth [53].

\section{Regulation of mRNA splicing}

Growing evidence supports a crucial role of constitutive and alternative RNA splicing in control of genes driving cancer phenotypes $[54,55]$. Thus, factors that genetically and epigenetically control activity of splicing machinery components must be tightly regulated to ensure splicing fidelity. Notably, protein arginine methylation is commonly seen on splicing machinery components. Moreover, proteome-wide profiling revealed enrichment of argininemethylated proteins implicated in control of RNA splicing, transport or degradation $[13,14,56,57]$.

Early studies identified PRMT5 as part of the 20S methylosome containing MEP50, pICln, SmD1, SmD3 and $\mathrm{SmB}$, in which the three $\mathrm{Sm}$ proteins were methylated by PRMT5 (Figure 3) $[5,58,59]$. Methylated Sm proteins with- in the methylosome are then transferred to tudor domain containing SMN (survival of motor neuron) protein and assembled into snRNPs (small nuclear ribonucleoprotein particles) along with the $6 \mathrm{~S}$ complex (pICln and Sm proteins) and snRNA. Assembled snRNPs in spliceosome then execute pre-mRNA splicing by recognizing sequence elements (e.g., 5'-, 3'- splice sites, branch point sequence and polypyrimidine tract) on pre-mRNA, in concert with other tans-acting splicing factors $[8,59,60]$. PRMT5 function in control of pre-mRNA splicing is conserved throughout evolution as it is detected in plants and flies [61-63].

In mouse neural progenitor cells, PRMT5 deletion causes defects in splicing of mRNAs with weak $5^{\prime}$ donor sites. Such defects take place in alternative splicing of Mdm4 in the absence of PRMT5, resulting in a shorter and less stable Mdm4 mRNA that activates the p53 pathway [64]. Indeed, PRMT5 knockdown or pharmacologic inhibition induces aberrant Mdm4 splicing enabling p53-mediated transcription of genes implicated in cell cycle and apoptosis, attenuating the growth of hematopoietic and solid tumors harboring wildtype p53 $[64,65]$. Likewise, altered Mdm4 splicing and p53 activation, seen upon PRMT5 inhibition, overcomes melanoma resistance to CDK4/6 inhibition [66].

Notably, cyclinD1/CDK4 also induces MEP50 phosphorylation which increases PRMT5 activity [67], and correspondingly, melanoma that were treated with CDK4/6 inhibitor and developed resistance also exhibited high PRMT5 activity [65]. Whether the increased activity of PRMT5 contribute to the resistance and thus justifies possible combination of PRMT5 inhibitors and CDK4/6 inhibitors, remain to be determined.

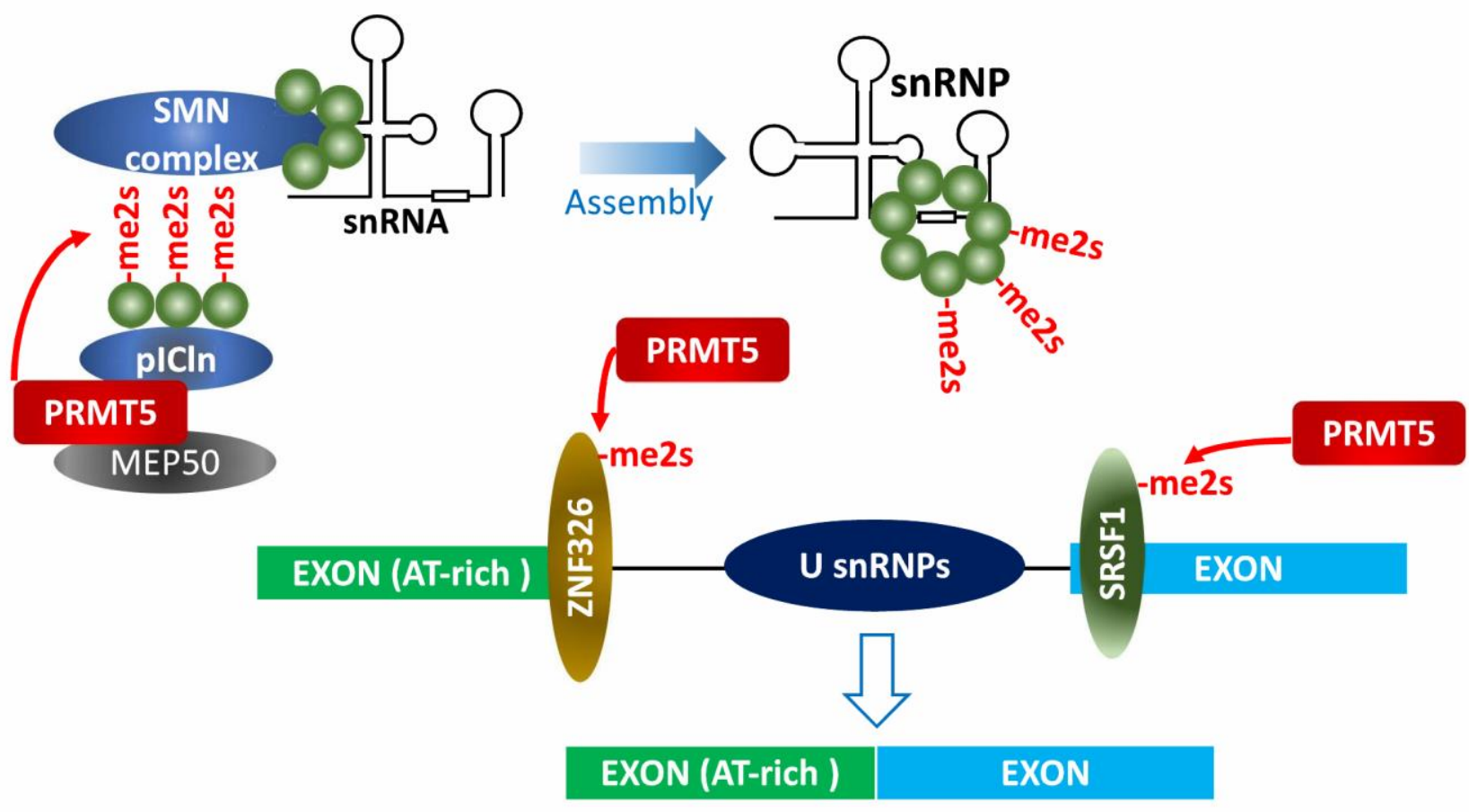

FIGURE 3: PRMT5 effect on splicing machinery. PRMT5 modification of splicing-machinery components is required for snRNP assembly and alternative splicing in pre-mRNAs, including those with a weak 5 ' splice site (A-T rich), ensuring splicing fidelity. 
PRMT5 control of splicing fidelity is also a factor in cMyc-driven lymphomagenesis. Gene sets enriched in $\mathrm{E} \mu$ myc B cell tumors include transcripts associated with snRNP biogenesis, RNA processing and RNA splicing, among them PRMT5. Myc- or PRMT5-depletion resulted in aberrant splicing (either exon skipping or retained introns) of genes associated with cell cycle arrest or apoptosis [68]. Consistently, large-scale proteomic profiling of PRMT5 substrates identified factors related to RNA processing $[13,57]$ Among them, SRSF1, a serine/arginine rich protein functioning in alternative splicing, is directly methylated by PRMT5. Defects in PRMT5-methylation attenuate survival of AML cells by altering SRSF1 interaction with a subset of mRNAs and splicing-associated proteins (Figure 3).

TIP60/KAT5, a histone lysine acetyltransferase that drives homologous recombination (HR) DNA repair, is also regulated by PRMT5-mediated alternative splicing. In response to DNA damage, PRMT5 facilitates alternative splicing of TIP60/KAT pre-mRNA to a TIP60a isoform with higher $\mathrm{H} 4$ lysine acetylase activity, which ensures error-free HR DNA repair and maintenance of genome integrity in hematopoietic cells [69].

In addition to PRMT5 methylation that alters its transcriptional activity, E2F1 is also implicated in regulation of alternative splicing following PRMT5-methylation. E2F1 methylation promotes recruitment of $\mathrm{p} 100 / \mathrm{TSN}$ as well as the snRNP spliceosome, which regulates splicing of E2F1 targets $[70,71]$. Further studies are required to clarify mechanisms underlying the balance between E2F1 control of transcription and alternative splicing.

Given that numerous splicing-related proteins are methylated on arginine, it is not surprising that PRMT inhibition evokes defects in splicing fidelity of genes critical to cancer $[13,56,57]$. PRMT5 inhibition or depletion suppresses glioblastoma (GBM) growth by impairing removal of retained introns in genes functioning in cell proliferation, anti-senescence and anti-apoptosis [72]. Tumor intrinsic alteration of splicing through the frequently seen mutation in RNA splicing factors (SRSF2, SF3B1 and U2AF1) in AML cells confers vulnerability to either PRMT1 inhibition (MS023, [73]), PRMT5 inhibition (GSK3203591, [74]), or both [14]. Notably, combined treatment with type I PRMT inhibitors (GSK3368715 or MS023) and PRMT5 inhibitors (GSK3326595 or GSK3203591) slows in vitro and in vivo growth of tumor cells more effectively than treatment with either alone [14, 75]. Proteomic profiling of tumor cells revealed that either treatment alone reduces methylation of distinct subsets of protein, while combination treatment reduces the methylation in a higher number of proteins that serve as substrates for either type I, type II or both PRMTs. Consistently, transcriptomic splicing analysis confirms increase of aberrant splicing events following combination compared to single drug treatment $[14,75]$.

\section{PRMT5 regulation of translation}

Tumor cells control protein translation as a means to adapt to tumor intrinsic and extrinsic stress conditions. PRMT5 reportedly interacts with and modifies (sDMA) RPS10 (ribosomal protein s10) which serves ribosome assembly.
Such modification facilitates RPS10's ability to interact with NPM1 (nucleophosmin 1, a factor functioning in ribosome assembly), which ensures proper ribosome assembly, and general protein synthesis, supporting tumor cell proliferation [76]. hnRNPA1, an IRES transacting factor (ITAF) regulating IRES-dependent mRNA translation, is also methylated by PRMT5. Such methylation facilitates interaction of hnRNPA1 with an ITAD with concomitant translation of cyclin D1 and c-Myc [77]. Given the importance of IRESdependent protein translation under stress conditions, PRMT5 control of IRES-dependent translation likely sustains oncogenic phenotypes under oxygen and nutrient deprivation, which are commonly seen in cancer.

\section{Control of growth factor signaling}

In addition to transcriptional activation of FGFR genes by PRMT5 in lung and colon cancers $[23,25,78,79]$, direct arginine methylation by PRMT5 regulates activity of several proteins functioning in growth factor signaling pathways crucial to the proliferation, differentiation and survival of cancer cells.

Arginine methylation of EGFR by PRMT5 occurs on a residue proximal to the auto-phosphorylated tyrosine following EGF-stimulation and thereby facilitates SHP recruitment and reduces ERK-activation and proliferation/migration of breast cancer cells [80]. Along the same line, genetic or pharmacologic (MTA, methylthioadenosine) inhibition of PRMT5 increases the amplitude of growth factor-driven RAS/ERK activation, by sustaining availability of activated CRAF by blocking PRMT5-driven methylation and degradation of CRAF (Figure 4) [81]. These studies suggest that PRMT5 inhibition increases oncogenic signaling - via amplifying RAS/ERK signaling. The cellular context, tissue dependence and genetic background that explain the oncogenic vs. tumor suppressor functions of PRMT5 require further studies.

By contrast, PDGFR (platelet derived growth factor receptor) signaling in oligodendrocyte progenitor cells is positively regulated by PRMT5-methylation [82]. PRMT5methylation of PDGFR $\alpha$ conceals the docking site for Cbl E3 ligase, which in turn increases PDGFR $\alpha$ availability and downstream activation of AKT/ERK signaling pathways required for proliferation [82].

NF-KB plays a crucial role tumorigenesis and is modified by PRMT5 in response to diverse cellular signals. As discussed above, PRMT5 activates NF-KB by direct methylation of the p65 subunit [45]. PRMT5 also interacts with the TRAIL receptor and confers resistance to TRAIL-induced apoptosis by increasing TRAIL-induced NF-KB activation, albeit, in a methyltransferase activity-independent manner [83]. PRMT5 inhibition blocks growth of multiple myeloma cells by abrogating NF-KB signaling. Mechanistically, PRMT5 methylation of TRIM21, an E3 ligase, inhibits TRIM21dependent monoubiquitination and degradation of IKK $\beta$ through selective autophagy [84].

TGF $\beta$ signaling can both up- or down-regulate target genes involved in growth and the epithelial-mesenchymaltransition. SKI, a SMAD-interacting transcriptional repressor, is methylated by the PRMT5-MEP50-SHARPIN 


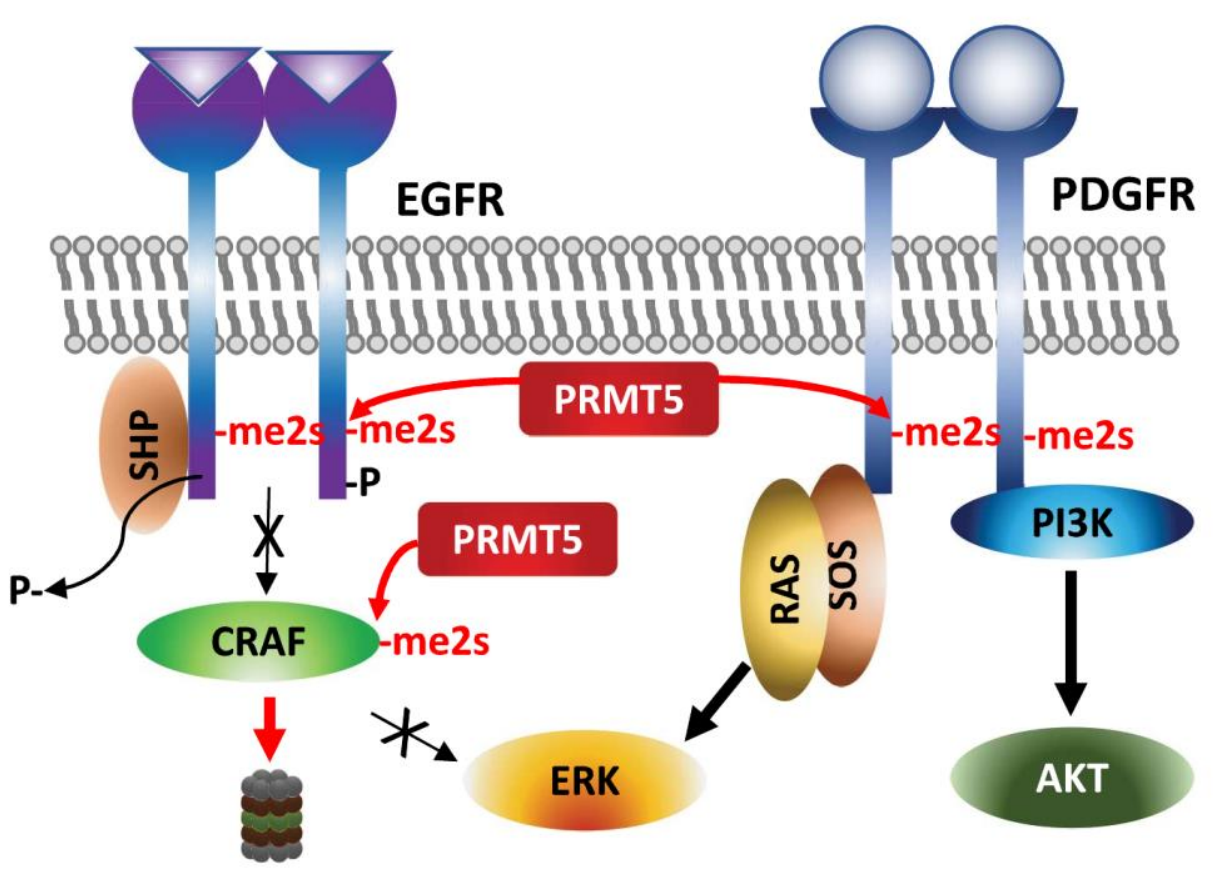

FIGURE 4: Regulation of growth factor receptors by PRMT5. Arginine methylations of the growth factor receptors EGFR and PDGFR affect ERK and AKT activation, respectively. complex, which fine-tunes transcriptional regulation of TGF $\beta$ signaling on a specific subset of genes [53].

\section{Control of the DNA damage response}

The DDR plays crucial roles in maintaining genomic stability by activating cell cycle checkpoints and DNA repair processes in response to anti-cancer therapies, including ionizing radiation and chemotherapy [85-87]. Protein methylation by PRMTs is among numerous post-translational modifications that control assembly and disassembly of DDR machinery as well as related gene expression (Figure 5).

PRMT5 regulates expression of cell cycle/apoptosisassociated genes by modifying p53, E2F-1 and KLF4 during the DDR. PRMT5 controls H2AX protein availability by transcriptional activation of RNF168, an E3 ligase introducing K63 ubiquitination on $\mathrm{N}$-terminal $\mathrm{K} 13$, thereby protecting H2AX from Smurf2-mediated K-48 degradative ubiquitination on C-terminal K119. Consequently, PRMT5 ensures formation of phosphorylated $\mathrm{H} 2 \mathrm{AX}(\mathrm{\gamma H} 2 \mathrm{AX})$ foci at DNA double strand break (DSB) for recruiting DNA repair proteins [88].

PRMT5 also directly modifies and controls components of DDR-associated pathways. For maturation of Okazaki fragments during replication, FEN1, a special DNA structure-specific flap endonuclease, which is important for DNA replication and repair, is recruited to replication foci by binding to PCNA (proliferating cell nuclear antigen). PRMT5 methylation of FEN1 at R192 facilitates its interaction with PCNA by inhibiting FEN1 phosphorylation at S187 by $C D K 1 /$ cyclin $A$ or $C D K 2 /$ cyclin $E$, ensuring interaction between FEN1 and PCNA for intact DNA replication and DNA repair processes at replication and repair foci [89]. Rad9, a component of Rad9-Rad1-Hus1 complex that plays a key role in $\mathrm{S} / \mathrm{M}$ and $\mathrm{G} 2 / \mathrm{M}$ cell cycle checkpoints in response to the DDR, is modified by PRMT5, a modification that activates cell cycle checkpoints by activation of the effector kinase CHK1 [90]. PRMT5 also functions in HRmediated DSB repair. RUVBL1, an AAA+ ATPase found in the TIP60 complex, interacts with and is methylated by PRMT5, facilitating effective demobilization of the DNAdissection inhibitor, 53BP1, from the DSB site. As a result, TIP60-mediated H4K16 acetylation disrupts binding of 53BP1 to H4K20me2 [91]. Alternative splicing dependent TIP60 activation may also underlie PRMT5 control of HR DNA repair in hematopoietic cells [69].

Top1 (DNA topoisomerase 1) relieves DNA supercoiling during replication and transcription by forming a transient and reversible protein-ssDNA-linked structure, Top1cc (Top1 cleavage complex), that is hydrolyzed by TDP1 (tyrosyl-DNA phosphodiesterase 1). Unresolved Top1cc complexes often cause DNA DSBs and the DDR upon replication or transcription. PRMT5-catalyzed methylation of two arginines in TDP1 directly enhances TDP1 catalytic activity and promotes formation of repair foci containing the XRCC-1 complex at Top1cc-induced DNA damaged sites by facilitating interaction with XRCC1, and thereby resolving trapped Top1cc [92].

\section{PRMT5 in tumor immunity}

Growing evidence points to a link between genetic and epigenetic alterations in oncogenesis and anti-tumor immune responses. PRMT5 depletion antagonizes melanoma growth in immunocompetent but not immunocompromised mice whereas PRMT5 overexpression accelerates tumor growth. Increased abundance of infiltrated immune cells seen upon PRMT5 inhibition coincides with enhanced anti-tumor immunity [93]. PRMT5 contributes to antitumor immunity by altering two distinct tumor intrinsic pathways. First, PRMT5 methylation of IFI16/IFI204, a DNA sensor that triggers IFN-I (type I interferon) responses 

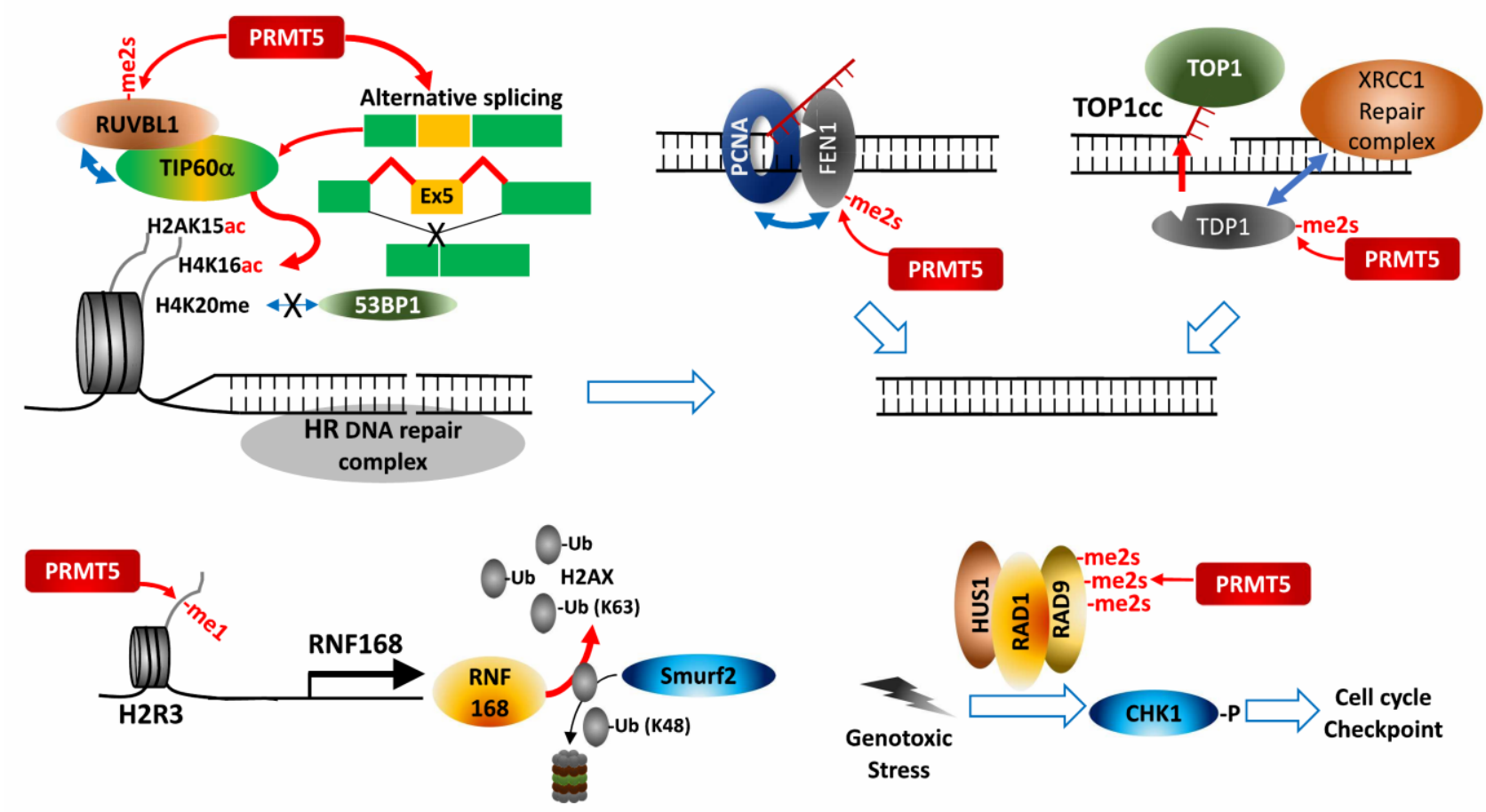

FIGURE 5: PRMT5 control of cell cycle and DNA repair. PRMT5 modify factors controlling cell cycle, thereby facilitating cell cycle checkpoint activation and homologous recombination-based DNA break repair.

through STING activation, suppresses STING activation and IFN-I/chemokine expression following stimuli (i.e. dsDNA; [93]). In parallel, PRMT5 was found to repress the expression of NLRC5, a master regulator of inflammasomes and antigen presentation pathways, including $\mathrm{MHCl}$ genes. Through the control of these complimentary pathways PRMT5 limits immune cell recruitment and activation as well as tumor recognition, which defines tumor immune evasion. In as much, PRMT5 inhibition is expected to enhance the response of cold (unresponsive) tumors to immune checkpoint therapy (ICT). Indeed, genetic or pharmacologic (GSK3326595) inhibition of PRMT5 sensitizes ICT-unresponsive cold melanoma (B16F10, or YUMM1.7) to anti-PD1 therapy [93].

Notably, PRMT5 plays several roles in hematopoiesis as in the development, activation and differentiation of diverse immune cells. Conditional PRMT5 knockout in hematopoietic cells causes bone marrow (BM) aplasia, due to loss of hematopoietic progenitor cells that exhibit severe defects in cytokine signaling [94]. Proteomic analysis of arginine-methylated peptides in human $T$ cells identified arginine-methylated components of the TCR (T cell receptor) and transcription factors regulating $T$ cell activation and differentiation [95]. TCR-induced PRMT5 [96] contributes to $T$ cell maintenance (proliferation, survival and differentiation) by inducing IL-2 production [97, 98]. PRMT5 facilitates cytokine signaling through intact splicing of common gamma chain $(\gamma \mathrm{c}) / \mathrm{IL} 2 \mathrm{RG}$ and JAK3 genes $[99,100]$ Further, PRMT5 promotes Th17 differentiation by activation of SREBP1-choresterol pathway along the RORyt axis
[101]. PRMT5 induction and subsequent Th1 and Th17 differentiation exemplify the pathological roles played by PRMT5 in autoimmune disorders, experimental autoimmune encephalomyelitis (EAE) and acute graft-versus-host diseases (aGVHD) [98, 101, 102].

Paradoxically, PRMT5 is also required for the suppressive function of regulatory T cells (Treg), which is essential to suppress autoimmunity. Mice with conditional PRMT5 knockout in Treg cells develop severe scurfy-like autoimmunity. Treg cells lacking PRMT5 or treated with PRMT5 inhibitors show loss of immunosuppressive function due to the loss of R51 methylation in FOXP3, a master regulator of Treg [103]. Notably, combination treatment of CD26Her2 mouse tumors with targeted therapy (anti-erbB2/neu antibody) plus a PRMT5 inhibitor (DS-437) enhanced antitumor effects through Treg suppression and augmented anti-tumor immunity [103]. Moreover, inhibitor screening identified PRMT1 methylation of FOXP3 as required for suppressive Treg function [104]. Further studies are needed define how systemic inhibition of PRMT5 will affect not only tumor cells, but various cell types found in the tumor microenvironment, including immune and other stromal cells.

\section{REGULATION OF PRMT5 EXPRESSION AND ACTIVITY IN CANCER}

PRMT5 expression is upregulated in most cancer types, and in most cases such upregulation is associated with poor patient survival. Given that genetic alterations (amplification, mutation, deletion) are rare in PRMT5 genes, epige- 
netic control of PRMT5 in cancer emerges as a key player in the control of its expression and activity (Figure 6).

\section{Transcriptional activation of PRMT5}

Several transcription factors reportedly regulate PRMT5 expression. Analysis of the proximal PRMT5 promoter identified CAATT boxes that are recognized by the transcription factor NF-Y and can induce PRMT5 transcription in prostate and lung cancer lines [105]. Myc and NF-KB also upregulate PRMT5 in Eu-myc B cells, GCB (germinal center B cell-like) DLBCL (diffuse large B-cell lymphoma) tumors, and $A B C$ (activated $B$ cell-like) tumors $[68,106]$. In AML harboring the MLL1 translocation, the polymerase-associated factor complex (PAFc), an epigenetic co-activator complex that contacts MLL1-fusion protein, is directly recruited to the PRMT5 promoter to induce PRMT5 expression [107].

\section{Regulation by microRNA}

micro RNAs also regulate PRMT5 expression in cancer cells. In transformed B cells, miR-19a, -25, -32, $-92 b$, and -96 negatively regulate PRMT5 expression [18]. Among them, miR-92b and -96 bind to the PRMT5 3'UTR (untranslated region) to block translation [108]. PRMT5 and miR-96 repress expression of each other via a negative feedback loop [109]. miR-1266 in PC and miR-16 and miR-4518 in glioma have been suggested to negatively regulate PRMT5 expression [110-112]. Of those, miR-16 and miR-4518 regulation of PRMT5 in glioma can be outcompeted by the long noncoding RNA (IncRNAs) LINC00015 and SNHG16, respectively $[110,112]$.
Regulation by the UPS (ubiquitin-proteasome system) The protein CHIP (carboxyl terminus of heat shock cognate 70-interacting protein), a chaperone-dependent E3 ligase functioning in protein-folding-associated degradation, reportedly promotes the proteasomal degradation of PRMT5 following treatment with the HSP90 inhibitor 17-AAG [113]. LINC01138, a InCRNA encoded in a genomic region frequently amplified in HCC, binds to and stabilizes PRMT5 protein by interfering with CHIP binding and ubiquitination [114]. Binding of PRMT5 to SHARPIN, a component of the LUBAC complex, implies a possible crosstalk between PRMT5-mediated methylation and LUBAC-driven linear ubiquitination $[40,53]$.

\section{Regulation by PTM}

PRMT5 activity is itself regulated by multiple PTMs including phosphorylation/dephosphorylation, methylation, acetylation and protein-protein interactions. The JAK2 mutation JAKV617F, found in most non-CML MPN (myeloproliferative neoplasia), facilitates JAK2 interaction with and phosphorylation of PRMT5, which attenuates methylase activity by preventing interaction with MEP50 [115]. A threonine residue within the PRMT5 C-terminal tail is phosphorylated by Akt/SGK, an activity that serves as a switch to control PRMT5 targeting to the plasma membrane via choice of differential interacting partners, a PDZ domain protein or 14-3-3, depending on phosphorylation status [116]. ROCK (RhoA-activated kinase) and MP (myosin phosphatase), respectively, phosphorylate and dephosphorylate PRMT5 threonine 80, to modulate PRMT5 activity, thereby pointing to a tumor suppressor role of MP

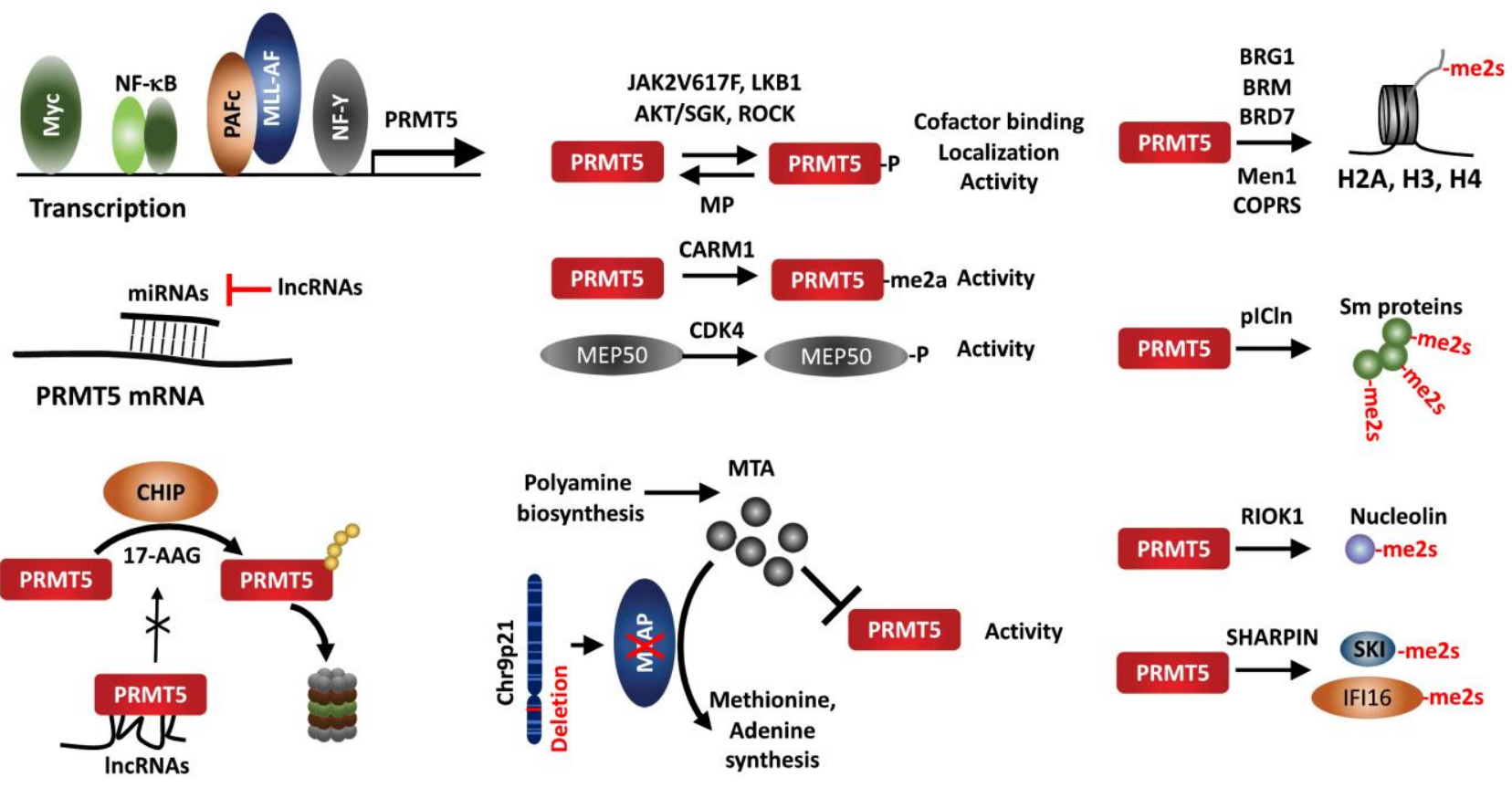

FIGURE 6: The pathways regulating PRMT5 in cancer. The activity, localization and protein-protein interaction are altered by indicated upstream components, posttranslational modification of PRMT5 or its adaptor protein, MEP50. PRMT5 interaction with adaptors serves to identify the substrates which will be methylated. PRMT5 activity is inhibited by the endogenous inhibitor, MTA, an MTAP substrate which is deleted in up to $30 \%$ of tumors. 
in HCC [117]. LKB1, a kinase with tumor suppressor function, phosphorylates multiple threonines (T132, 139 and 144 ) in the PRMT5 TIM-barrel domains required for MEP50, pICln and RIOK1 interaction, suppressing PRMT5 enzymatic activity [118]. PRMT5 itself is arginine-methylated by CARM1 (PRMT4) in the erythroleukemia cells Lys-562, which is essential for PRMT5 methyltransferase activity to repress human $\gamma$-globin expression via H4R3me2s [119]. Moreover, PRMT5 adaptors are subject to modifications that impact overall PRMT5 activity. For example, MEP50/WDR77 phosphorylation by CDK4 increases PRMT5 activity via an undefined mechanism [67]. MEP50/WDR77 is deacetylated by SIRT7 in HCT116 cells, which interfere with PRMT5/WDR77 interaction and repress PRMT5 activity [120]. Whether the impaired SIRT7/WDR77 activity and HCT116 growth are PRMT5 dependent, remains to be established.

\section{Regulation by protein-protein interaction (adaptors)}

PRMT5 recruitment to a given substrate resulting in its methylation depends on its associated adaptor proteins, which define its conformation, activity and subcellular localization. PRMT5 interaction with MEP50/WDR77 in hetero-octameric complex increases its stability and activity [11]. PRMT5 modification of histone tails require PRMT5 interaction with BRG1, hBRM, BRD7, components of the chromatin remodeling complex $[16,17,19,26]$ or with the transcription repressor (Men1) [20, 21]. COPR5 interacts with PRMT5 and N-terminus of $\mathrm{H} 4$, facilitating H4R3 methylation [121]. Likewise, pICln is required for PRMT5 methylation of Sm proteins [122-124], RIOK1 for PRMT5 methylation of nucleolin [124], and SHARPIN for PRMT5 methylation of SKI and IFI16/IFI204 [53, 93]. Thus, alteration of adaptor proteins is expected to modulate PRMT5 activity and function, exemplified in MEP50 phosphorylation/acetylation [67, 120], Men1 mutation [20], and SHARPIN expression [53].

\section{Regulation by endogenous inhibitors}

PRMT5 activity is also limited by the endogenous inhibitor, 5 'methylthioadenosine (MTA), a byproduct of the polyamine synthesis pathway, which is metabolized by methylthioadenosine phosphorylase (MTAP). However, due to proximity to CDKN2A on Chr9p21, MTAP is co-deleted with CDKN2A in $15-40 \%$ of human cancers, resulting in accumulation of unmetabolized MTA and attenuation of endogenous PRMT5 activity. Accordingly, MTAP loss confers vulnerability to further inhibition of PRMT5 or of type I PRMTs $[75,125-128]$.

\section{THERAPEUTIC INTERVENTIONS BASED ON PRMT5 Strategies to target PRMT5}

Given that PRMT5 participates in a wide range of physiological processes, crucial for maintenance of cancer phenotypes, perturbation of PRMT5 is expected to provide novel means to treat cancer. Along these lines, PRMT5 plays an important role in embryonic stem and tissue specific stem/precursor cells $[15,94,129,130]$, and corresponding- ly, PRMT5 contributes to self-renewal of cancer stem cells (CSCs). This is exemplified by the activation of FOXP1 transcription in breast cancer stem cells [38] and DVL3 transcription, an activator of Wnt/ $\beta$-catenin, in CML-LSCs (leukemic stem cells) [131], which were linked with PRMT5 activity. Given the pivotal roles of CSCs in drug-resistance and relapse, PRMT5 inhibition may provide a novel therapeutic modality for cancer-initiating cells.

Significantly, PRMT5 inhibition in established tumors could disable mechanisms protecting tumor cells from DNA damaging stress brought on by radiotherapy and chemotherapy. Indeed, PRMT5 depletion/inhibition sensitizes tumor cells to drugs inducing the DDR, exemplified by cytarabine (MLL-rearranged leukemia, [132]), PARP inhibitors (AML, [69]) and camptothecin, a topoisomerase inhibitor [92].

Emerging evidence suggests that disruption of splicing fidelity by PRMT5 depletion/inhibition could have an anticancer effect $[72,130]$. In support of this idea, the presence of a frequently occurring splicing factor (SF) mutation (SRSF2 ${ }^{\mathrm{P} 95 \mathrm{H}}$ ) or treatment with an SF3B1 inhibitor renders AML cells vulnerable to PRMT5 and/or PRMT1 inhibition [14]. Likewise, combinatorial inhibition of type I and type II PRMTs resulted in an enhanced therapeutic effect by increasing aberrant spliced targets seen upon inhibition of both PRMTs [75].

The unprecedent success of ICT is hampered by limited responses seen in a fraction of patients or by development of resistance. PRMT5 activity suppresses anti-tumor immune responses by supporting tumor intrinsic mechanisms allowing immune evasion, Treg function, and repression of IFN-1 and $\mathrm{MHCl}$ pathways $[93,103]$, providing a rationale for combining PRMT5 inhibitors with ICT. However, given the complexity of the tumor microenvironment, further studies are needed to determine how systemic PRMT5 inhibition, either singly or in combination with ICT, would affect anti-tumor immunity.

Identification of novel biomarkers is important to allow stratification of patients for precision anti-cancer treatment and improve therapeutic efficacy. The presence of SF mutations and MTAP homozygous deletion represents examples of biomarkers that aid in patient stratification for targeting PRMT5 [14, 75, 125-127].

\section{PRMT5 inhibitors in clinical trials}

The first in-class PRMT5 inhibitor, EPZ015666, was reported in 2015 [133]. EPZ015666 binds to the PRMT5 peptide binding site, which endows peptide-competitive and SAMuncompetitive feature of compound [133]. An improved compound, GSK3326595 (EPZ015938), is currently under two clinical trials, phase I dose escalating study in solid tumors and non-Hodgkin lymphoma (NCT02783300) and phase I safety and clinical activity study in myelodysplastic syndrome and AML (NCT03614728). In these trials, GSK3326595 monotherapy as well as combination treatment with Pembrolizumab (an anti-PD1 antibody) (NCT02783300) or 5-azacytidine (NCT03614728) will be evaluated. JNJ-64619178, a SAM-competitive inhibitor, binds to SAM- and the protein substrate binding domain of 
PRMT5 is being tested in a phase I clinical trial (NCT03573310) against B cell non-Hodgkin lymphoma and solid tumors. A different SAM-competitive PRMT5 inhibitor PF-06939999, is under phase I dose escalating study in advanced or metastatic solid tumors (NCT03854227). Given the essential roles PRMT5 plays in fundamental cellular processes, it would be important to monitor possible toxicity following systemic administration of PRMT5 inhibitors. As important, efforts to improve therapeutic efficacy, probably upon combination with other therapies, may allow one to reduce PRMT5 concentration and possible toxicities.

\section{FUTURE PERSPECTIVES/EPILOGUE}

PRMT5 regulates numerous cellular pathways but exerts major effects on histone function in transcription and RNA splicing. PRMT5 directly methylates many proteins to control their subcellular localization, protein-protein interactions, stability or activity. Many of these contribute to oncogenic transformation, and thus evaluation of potential PRMT5 inhibitors is warranted. Given the importance of PRMT5 in oncogenesis, deciphering mechanisms underlying PRMT5 expression, activity as well as subcellular localization will advance the development of advanced PRMT5related therapeutic modalities. Thus far, researchers have largely focused on PRMT5 control of tumor intrinsic changes; however, PRMT5 effects on the tumor microenvironment, and on immune cells in particular, should be assessed in future studies. Another current knowledge gap is understanding dynamic cross talk between different PRMT family members, as exemplified by recent studies showing that PRMT1 and PRMT5 modification of a single protein may regulate opposing functions. Importantly, inhibition of one PRMT member may impact activity of another, as

\section{REFERENCES}

1. Baldwin GS, Carnegie PR (1971). Specific enzymic methylation of an arginine in the experimental allergic encephalomyelitis protein from human myelin. Science 171(3971): 579-581. doi: 10.1126/science.171.3971.579

2. Paik WK, Kim S (1971). Protein methylation. Science 174(4005): 114-119. doi: 10.1126/science.174.4005.114

3. Reitz RC, Lands WE, Christie WW, Holman RT (1968). Effects of ethylenic bond position upon acyltransferase activity with isomeric cis,cis-octadecadienoyl coenzyme A thiol esters. J Biol Chem 243(9): 2241-2246. doi: 10.1016/0005-2760(69)90215-x

4. Lin WJ, Gary JD, Yang MC, Clarke S, Herschman HR (1996). The mammalian immediate-early TIS21 protein and the leukemiaassociated BTG1 protein interact with a protein-arginine $\mathrm{N}$ methyltransferase. J Biol Chem 271(25): 15034-15044. doi: 10.1074/jbc.271.25.15034

5. Krapivinsky G, Pu W, Wickman K, Krapivinsky L, Clapham DE (1998). pICln binds to a mammalian homolog of a yeast protein involved in regulation of cell morphology. J Biol Chem 273(18): 10811-10814. doi: 10.1074/jbc.273.18.10811

6. Pollack BP, Kotenko SV, He W, Izotova LS, Barnoski BL, Pestka S (1999). The human homologue of the yeast proteins Skb1 and Hsl7p interacts with Jak kinases and contains protein methyltransferase shown for increased PRMT5 methylation upon PRMT1 inhibition. Potential interplay among family members is critical to understand when using selective inhibitors, and in some cases, may justify targeting multiple PRMT members. Lastly, PRMT5 activity is reportedly downregulated in $30 \%$ of human cancers, due to its negative regulation by MTA, which is enhanced upon MTAP-co-deletion with CDKN2A The notion that genetic-based stratification for PRMT5 inhibition can help map tumors vulnerable to PRMT5 targeting remains attractive and deserves to be further assessed.

\section{ACKNOWLEDGMENTS}

Authors thank members of the Ronai lab for discussion. Support by NCl grants R35CA197465, CA128814 and DOD grant W81XWH-18-1-216 (to ZR) are gratefully acknowledged.

\section{CONFLICT OF INTEREST}

$Z R$ is a co-founder and serves as scientific advisor to Pangea Therapeutics. HK declares no competing interests.

\section{COPYRIGHT}

(C) $2020 \mathrm{Kim}$ and Ronai. This is an open-access article released under the terms of the Creative Commons Attribution (CC BY) license, which allows the unrestricted use, distribution, and reproduction in any medium, provided the original author and source are acknowledged.

Please cite this article as: Hyungsoo Kim and Ze'ev A. Ronai (2020). PRMT5 function and targeting in cancer. Cell Stress 4(8): 199-215. doi: $10.15698 /$ cst2020.08.228

activity. J Biol Chem 274(44): 31531-31542. doi: 10.1074/jbc. 274.44 .31531

7. Rho J, Choi S, Seong YR, Cho WK, Kim SH, Im DS (2001). Prmt5, which forms distinct homo-oligomers, is a member of the proteinarginine methyltransferase family. J Biol Chem 276(14): 11393-11401. doi: $10.1074 /$ jbc.M008660200

8. Branscombe TL, Frankel A, Lee JH, Cook JR, Yang Z, Pestka S, Clarke $S$ (2001). PRMT5 (Janus kinase-binding protein 1) catalyzes the formation of symmetric dimethylarginine residues in proteins. J Biol Chem 276(35): 32971-32976. doi: 10.1074/jbc.M105412200

9. Blanc RS, Richard S (2017). Arginine Methylation: The Coming of Age. Mol Cell 65(1): 8-24. doi: 10.1016/j.molcel.2016.11.003

10. Jarrold J, Davies CC (2019). PRMTs and Arginine Methylation: Cancer's Best-Kept Secret? Trends Mol Med 25(11): 993-1009. doi: 10.1016/j.molmed.2019.05.007

11. Antonysamy S, Bonday Z, Campbell RM, Doyle B, Druzina Z, Gheyi T, Han B, Jungheim LN, Qian $Y$, Rauch C, Russell M, Sauder JM, Wasserman SR, Weichert K, Willard FS, Zhang A, Emtage S (2012). Crystal structure of the human PRMT5:MEP50 complex. Proc Nat Acad Sci U S A 109(44): 17960-17965. doi: 10.1073/pnas.1209814109

12. Ho MC, Wilczek C, Bonanno JB, Xing L, Seznec J, Matsui T, Carter LG, Onikubo T, Kumar PR, Chan MK, Brenowitz M, Cheng RH, Reimer 
$U$, Almo SC, Shechter D (2013). Structure of the arginine methyltransferase PRMT5-MEP50 reveals a mechanism for substrate specificity. PLoS One 8(2): e57008. doi: 10.1371/journal.pone.0057008

13. Musiani D, Bok J, Massignani E, Wu L, Tabaglio T, Ippolito MR, Cuomo A, Ozbek U, Zorgati H, Ghoshdastider U, Robinson RC, Guccione E, Bonaldi T (2019). Proteomics profiling of arginine methylation defines PRMT5 substrate specificity. Sci Signal 12(575): eaat8388. doi: 10.1126/scisignal.aat8388

14. Fong JY, Pignata L, Goy PA, Kawabata KC, Lee SC, Koh CM, Musiani $D$, Massignani E, Kotini AG, Penson A, Wun CM, Shen $Y$, Schwarz M, Low DH, Rialdi A, Ki M, Wollmann H, Mzoughi S, Gay F, Thompson C, Hart T, Barbash O, Luciani GM, Szewczyk MM, Wouters BJ, Delwel R, Papapetrou EP, Barsyte-Lovejoy D, Arrowsmith CH, Minden MD, et al. (2019). Therapeutic Targeting of RNA Splicing Catalysis through Inhibition of Protein Arginine Methylation. Cancer Cell 36(2): 194-209 e199. doi: 10.1016/j.ccell.2019.07.003

15. Tee WW, Pardo M, Theunissen TW, Yu L, Choudhary JS, Hajkova P, Surani MA (2010). Prmt5 is essential for early mouse development and acts in the cytoplasm to maintain ES cell pluripotency. Genes Dev 24(24): 2772-2777. doi: 10.1101/gad.606110

16. Pal S, Yun R, Datta A, Lacomis L, Erdjument-Bromage $H$, Kumar J, Tempst $\mathrm{P}$, Sif S (2003). mSin3A/histone deacetylase 2- and PRMT5containing Brg1 complex is involved in transcriptional repression of the Myc target gene cad. Mol Cell Biol 23(21): 7475-7487. doi: $10.1128 / \mathrm{mcb} .23 .21 .7475-7487.2003$

17. Pal $S$, Vishwanath $S N$, Erdjument-Bromage $H$, Tempst $P$, Sif $S$ (2004). Human SWI/SNF-associated PRMT5 methylates histone H3 arginine 8 and negatively regulates expression of ST7 and NM23 tumor suppressor genes. Mol Cell Biol 24(21): 9630-9645. doi: 10.1128/MCB.24.21.9630-9645.2004

18. Wang L, Pal S, Sif S (2008). Protein arginine methyltransferase 5 suppresses the transcription of the RB family of tumor suppressors in leukemia and lymphoma cells. Mol Cell Biol 28(20): 6262-6277. doi: 10.1128/MCB.00923-08

19. Tae S, Karkhanis V, Velasco K, Yaneva M, Erdjument-Bromage $H$, Tempst $P$, Sif $S$ (2011). Bromodomain protein 7 interacts with PRMT5 and PRC2, and is involved in transcriptional repression of their target genes. Nucleic Acids Res 39(13): 5424-5438. doi: 10.1093/nar/gkr170

20. Gurung B, Feng Z, Iwamoto DV, Thiel A, Jin G, Fan CM, Ng JM, Curran T, Hua X (2013). Menin epigenetically represses Hedgehog signaling in MEN1 tumor syndrome. Cancer Res 73(8): 2650-2658. doi: 10.1158/0008-5472.CAN-12-3158

21. Gurung B, Feng Z, Hua X (2013). Menin directly represses Gli1 expression independent of canonical Hedgehog signaling. Mol Cancer Res 11(10): 1215-1222. doi: 10.1158/1541-7786.MCR-13-0170

22. Tarighat SS, Santhanam R, Frankhouser D, Radomska HS, Lai $H$, Anghelina $M$, Wang $H$, Huang $X$, Alinari L, Walker A, Caligiuri MA, Croce CM, Li L, Garzon R, Li C, Baiocchi RA, Marcucci G (2016). The dual epigenetic role of PRMT5 in acute myeloid leukemia: gene activation and repression via histone arginine methylation. Leukemia 30(4): 789-799. doi: 10.1038/leu.2015.308

23. Jing $P$, Zhao $N$, Ye M, Zhang $Y$, Zhang Z, Sun J, Wang Z, Zhang J, Gu $Z$ (2018). Protein arginine methyltransferase 5 promotes lung cancer metastasis via the epigenetic regulation of miR-99 family/FGFR3 signaling. Cancer Lett 427: 38-48. doi: 10.1016/j.canlet.2018.04.019

24. Karkhanis V, Alinari L, Ozer HG, Chung J, Zhang X, Sif S, Baiocchi RA (2020). Protein arginine methyltransferase 5 represses tumor suppressor miRNAs that down-regulate CYCLIN D1 and C-MYC expression in aggressive B-cell lymphoma. J Biol Chem 295(5): 11651180. doi: 10.1074/jbc.RA119.008742
25. Zhang B, Dong S, Zhu R, Hu C, Hou J, Li Y, Zhao Q, Shao X, Bu Q, Li $\mathrm{H}, \mathrm{Wu} Y$, Cen $X$, Zhao $Y$ (2015). Targeting protein arginine methyltransferase 5 inhibits colorectal cancer growth by decreasing arginine methylation of elF4E and FGFR3. Oncotarget 6(26): 2279922811. doi: 10.18632/oncotarget. 4332

26. Deng X, Shao G, Zhang HT, Li C, Zhang D, Cheng L, Elzey BD, Pili R, Ratliff TL, Huang J, Hu CD (2017). Protein arginine methyltransferase 5 functions as an epigenetic activator of the androgen receptor to promote prostate cancer cell growth. Oncogene 36(9): 1223-1231. doi: 10.1038/onc.2016.287

27. Liu F, Xu Y, Lu X, Hamard PJ, Karl DL, Man N, Mookhtiar AK, Martinez C, Lossos IS, Sun J, Nimer SD (2020). PRMT5-mediated histone arginine methylation antagonizes transcriptional repression by polycomb complex PRC2. Nucleic Acids Res 48(6): 2956-2968. doi: 10.1093/nar/gkaa065

28. Scaglione A, Patzig J, Liang J, Frawley R, Bok J, Mela A, Yattah C, Zhang J, Teo SX, Zhou T, Chen S, Bernstein E, Canoll P, Guccione E, Casaccia P (2018). PRMT5-mediated regulation of developmental myelination. Nat Commun 9(1): 2840. doi: 10.1038/s41467-018 04863-9

29. Liu R, Gao J, Yang Y, Qiu R, Zheng Y, Huang W, Zeng Y, Hou Y, Wang S, Leng S, Feng D, Yu W, Sun G, Shi $H$, Teng $X$, Wang $Y$ (2018). PHD finger protein 1 (PHF1) is a novel reader for histone H4R3 symmetric dimethylation and coordinates with PRMT5-WDR77/CRL4B complex to promote tumorigenesis. Nucleic Acids Res 46(13): 6608-6626. doi 10.1093/nar/gky461

30. Tamburri S, Lavarone E, Fernandez-Perez D, Conway E, Zanotti M, Manganaro D, Pasini D (2020). Histone H2AK119 Mono-Ubiquitination Is Essential for Polycomb-Mediated Transcriptional Repression. Mol Cell 77(4): 840-856 e845. doi: 10.1016/j.molcel.2019.11.021

31. Zhao Q, Rank G, Tan YT, Li H, Moritz RL, Simpson RJ, Cerruti L, Curtis DJ, Patel DJ, Allis CD, Cunningham JM, Jane SM (2009). PRMT5mediated methylation of histone H4R3 recruits DNMT3A, coupling histone and DNA methylation in gene silencing. Nat Struct Mol Biol 16(3): 304-311. doi: 10.1038/nsmb.1568

32. Migliori V, Muller J, Phalke S, Low D, Bezzi M, Mok WC, Sahu SK, Gunaratne J, Capasso P, Bassi C, Cecatiello V, De Marco A, Blackstock W, Kuznetsov V, Amati B, Mapelli M, Guccione E (2012). Symmetric dimethylation of H3R2 is a newly identified histone mark that supports euchromatin maintenance. Nat Struct Mol Biol 19(2): 136144. doi: 10.1038/nsmb.2209

33. Yuan CC, Matthews AG, Jin Y, Chen CF, Chapman BA, Ohsumi TK, Glass KC, Kutateladze TG, Borowsky ML, Struhl K, Oettinger MA (2012). Histone H3R2 symmetric dimethylation and histone H3K4 trimethylation are tightly correlated in eukaryotic genomes. Cell Rep 1(2): 83-90. doi: 10.1016/j.celrep.2011.12.008

34. Lorton BM, Harijan RK, Burgos ES, Bonanno JB, Almo SC, Shechter D (2020). A Binary Arginine Methylation Switch on Histone $\mathrm{H} 3$ Arginine 2 Regulates Its Interaction with WDR5. Biochemistry. doi: 10.1021/acs.biochem.0c00035

35. Guccione E, Bassi C, Casadio F, Martinato F, Cesaroni M, Schuchlautz H, Luscher B, Amati B (2007). Methylation of histone H3R2 by PRMT6 and H3K4 by an MLL complex are mutually exclusive. Nature 449(7164): 933-937. doi: 10.1038/nature06166

36. Kirmizis A, Santos-Rosa $H$, Penkett CJ, Singer MA, Vermeulen M, Mann M, Bahler J, Green RD, Kouzarides T (2007). Arginine methylation at histone H3R2 controls deposition of H3K4 trimethylation. Nature 449(7164): 928-932. doi: 10.1038/nature06160

37. Kirmizis A, Santos-Rosa H, Penkett CJ, Singer MA, Green RD, Kouzarides T (2009). Distinct transcriptional outputs associated with mono- and dimethylated histone H3 arginine 2. Nat Struct Mol Biol 16(4): 449-451. doi: 10.1038/nsmb.1569 
38. Chiang K, Zielinska AE, Shaaban AM, Sanchez-Bailon MP, Jarrold J, Clarke TL, Zhang J, Francis A, Jones L, Smith S, Barbash O, Guccione E, Farnie G, Smalley MJ, Davies CC (2017). PRMT5 Is a Critical Regulator of Breast Cancer Stem Cell Function via Histone Methylation and FOXP1 Expression. Cell Rep 21(12): 3498-3513. doi: 10.1016/j.celrep.2017.11.096

39. Cao L, Wu G, Zhu J, Tan Z, Shi D, Wu X, Tang M, Li Z, Hu Y, Zhang S, Yu R, Mo S, Wu J, Song E, Li M, Song L, Li J (2019). Genotoxic stresstriggered beta-catenin/JDP2/PRMT5 complex facilitates reestablishing glutathione homeostasis. Nat Commun 10(1): 3761 . doi: 10.1038/s41467-019-11696-7

40. Fu T, Lv X, Kong $Q$, Yuan C (2017). A novel SHARPIN-PRMT5H3R2me1 axis is essential for lung cancer cell invasion. Oncotarget 8(33): 54809-54820. doi: 10.18632/oncotarget.18957

41. Jansson M, Durant ST, Cho EC, Sheahan S, Edelmann M, Kessler B, La Thangue NB (2008). Arginine methylation regulates the p53 response. Nat Cell Biol 10(12): 1431-1439. doi: 10.1038/ncb1802

42. Li Y, Chitnis N, Nakagawa H, Kita Y, Natsugoe S, Yang Y, Li Z, Wasik M, Klein-Szanto AJ, Rustgi AK, Diehl JA (2015). PRMT5 is required for lymphomagenesis triggered by multiple oncogenic drivers. Cancer Discov 5(3): 288-303. doi: 10.1158/2159-8290.CD-14-0625

43. Cho EC, Zheng S, Munro S, Liu G, Carr SM, Moehlenbrink J, Lu YC, Stimson L, Khan O, Konietzny R, McGouran J, Coutts AS, Kessler B, Kerr DJ, Thangue NB (2012). Arginine methylation controls growth regulation by E2F-1. EMBO J 31(7): 1785-1797. doi: 10.1038/emboj.2012.17

44. Zheng S, Moehlenbrink J, Lu YC, Zalmas LP, Sagum CA, Carr S, McGouran JF, Alexander L, Fedorov O, Munro S, Kessler B, Bedford MT, Yu Q, La Thangue NB (2013). Arginine methylation-dependent reader-writer interplay governs growth control by E2F-1. Mol Cell 52(1): 37-51. doi: 10.1016/j.molcel.2013.08.039

45. Wei H, Wang B, Miyagi M, She Y, Gopalan B, Huang DB, Ghosh G, Stark GR, Lu T (2013). PRMT5 dimethylates R30 of the p65 subunit to activate NF-kappaB. Proc Natl Acad Sci U S A 110(33): 13516-13521. doi: $10.1073 /$ pnas.1311784110

46. Reintjes A, Fuchs JE, Kremser L, Lindner HH, LiedI KR, Huber LA, Valovka T (2016). Asymmetric arginine dimethylation of RelA provides a repressive mark to modulate TNFalpha/NF-kappaB response. Proc Natl Acad Sci U S A 113(16): 4326-4331. doi: 10.1073/pnas.1522372113

47. Gamper AM, Qiao X, Kim J, Zhang L, DeSimone MC, Rathmell WK, Wan $Y$ (2012). Regulation of KLF4 turnover reveals an unexpected tissue-specific role of pVHL in tumorigenesis. Mol Cell 45(2): 233-243. doi: 10.1016/j.molcel.2011.11.031

48. Hu D, Gur M, Zhou Z, Gamper A, Hung MC, Fujita N, Lan L, Bahar I, Wan $Y$ (2015). Interplay between arginine methylation and ubiquitylation regulates KLF4-mediated genome stability and carcinogenesis. Nat Commun 6: 8419. doi: 10.1038/ncomms9419.

49. Liu L, Zhao X, Zhao L, Li J, Yang H, Zhu Z, Liu J, Huang G (2016). Arginine Methylation of SREBP1a via PRMT5 Promotes De Novo Lipogenesis and Tumor Growth. Cancer Res 76(5): 1260-1272. doi: 10.1158/0008-5472.CAN-15-1766

50. Yu J, Yu J, Mani RS, Cao Q, Brenner CJ, Cao X, Wang X, Wu L, Li J, Hu M, Gong Y, Cheng H, Laxman B, Vellaichamy A, Shankar S, Li Y, Dhanasekaran SM, Morey R, Barrette T, Lonigro RJ, Tomlins SA, Varambally S, Qin ZS, Chinnaiyan AM (2010). An integrated network of androgen receptor, polycomb, and TMPRSS2-ERG gene fusions in prostate cancer progression. Cancer Cell 17(5): 443-454. doi: 10.1016/j.ccr.2010.03.018

51. Mounir Z, Korn JM, Westerling $T$, Lin F, Kirby CA, Schirle $M$, McAllister G, Hoffman G, Ramadan N, Hartung A, Feng Y, Kipp DR,
Quinn C, Fodor M, Baird J, Schoumacher M, Meyer R, Deeds J, Buchwalter G, Stams T, Keen N, Sellers WR, Brown M, Pagliarini RA (2016). ERG signaling in prostate cancer is driven through PRMT5dependent methylation of the Androgen Receptor. Elife 5: e13964. doi: 10.7554/eLife.13964

52. Lu X, Fernando TM, Lossos C, Yusufova N, Liu F, Fontan L, Durant M, Geng H, Melnick J, Luo Y, Vega F, Moy V, Inghirami G, Nimer S, Melnick AM, Lossos IS (2018). PRMT5 interacts with the BCL6 oncoprotein and is required for germinal center formation and lymphoma cell survival. Blood 132(19): 2026-2039. doi: 10.1182/blood-2018-02-831438

53. Tamiya $H$, Kim $H$, Klymenko $O$, Kim H, Feng $Y$, Zhang $T$, Han JY, Murao A, Snipas SJ, Jilaveanu L, Brown K, Kluger H, Zhang H, Iwai K, Ronai ZA (2018). SHARPIN-mediated regulation of protein arginine methyltransferase 5 controls melanoma growth. J Clin Invest 128(1): 517-530. doi: 10.1172/JCI95410

54. Dvinge $H$, Kim E, Abdel-Wahab O, Bradley RK (2016). RNA splicing factors as oncoproteins and tumour suppressors. Nat Rev Cancer 16(7): 413-430. doi: 10.1038/nrc.2016.51

55. Bonnal SC, Lopez-Oreja I, Valcarcel J (2020). Roles and mechanisms of alternative splicing in cancer - implications for care. Nat Rev Clin Oncol. doi: 10.1038/s41571-020-0350-x

56. Larsen SC, Sylvestersen KB, Mund A, Lyon D, Mullari M, Madsen MV, Daniel JA, Jensen $L$, Nielsen ML (2016). Proteome-wide analysis of arginine monomethylation reveals widespread occurrence in human cells. Sci Signal 9(443): rs9. doi: 10.1126/scisignal.aaf7329

57. Radzisheuskaya A, Shliaha PV, Grinev V, Lorenzini E, Kovalchuk S, Shlyueva D, Gorshkov V, Hendrickson RC, Jensen ON, Helin K (2019). PRMT5 methylome profiling uncovers a direct link to splicing regulation in acute myeloid leukemia. Nat Struct Mol Biol 26(11): 9991012. doi: 10.1038/s41594-019-0313-z

58. Friesen WJ, Paushkin S, Wyce A, Massenet S, Pesiridis GS, Van Duyne G, Rappsilber J, Mann M, Dreyfuss G (2001). The methylosome, a $20 \mathrm{~S}$ complex containing JBP1 and $\mathrm{pICln}$, produces dimethylargininemodified Sm proteins. Mol Cell Biol 21(24): 8289-8300. doi: 10.1128/MCB.21.24.8289-8300.2001

59. Meister G, Eggert C, Buhler D, Brahms H, Kambach C, Fischer U (2001). Methylation of Sm proteins by a complex containing PRMT5 and the putative $U$ snRNP assembly factor pICln. Curr Biol 11(24): 1990-1994. doi: 10.1016/s0960-9822(01)00592-9

60. Paknia E, Chari A, Stark H, Fischer U (2016). The Ribosome Cooperates with the Assembly Chaperone pICIn to Initiate Formation of snRNPs. Cell Rep 16(12): 3103-3112. doi: 10.1016/j.celrep.2016.08.047

61. Gonsalvez GB, Rajendra TK, Tian L, Matera AG (2006). The Smprotein methyltransferase, dart5, is essential for germ-cell specification and maintenance. Curr Biol 16(11): 1077-1089. doi: 10.1016/j.cub.2006.04.037

62. Deng X, Gu L, Liu C, Lu T, Lu F, Lu Z, Cui P, Pei Y, Wang B, Hu S, Cao $X$ (2010). Arginine methylation mediated by the Arabidopsis homolog of PRMT5 is essential for proper pre-mRNA splicing. Proc Natl Acad Sci U S A 107(44): 19114-19119. doi: 10.1073/pnas.1009669107

63. Sanchez SE, Petrillo E, Beckwith EJ, Zhang X, Rugnone $M L$, Hernando CE, Cuevas JC, Godoy Herz MA, Depetris-Chauvin A, Simpson CG, Brown JW, Cerdan PD, Borevitz JO, Mas P, Ceriani MF, Kornblihtt AR, Yanovsky MJ (2010). A methyl transferase links the circadian clock to the regulation of alternative splicing. Nature 468(7320): 112-116. doi: 10.1038/nature09470

64. Bezzi M, Teo SX, Muller J, Mok WC, Sahu SK, Vardy LA, Bonday ZQ, Guccione E (2013). Regulation of constitutive and alternative splicing by PRMT5 reveals a role for Mdm4 pre-mRNA in sensing defects in the 
spliceosomal machinery. Genes Dev 27(17): 1903-1916. doi: 10.1101/gad.219899.113

65. Gerhart SV, Kellner WA, Thompson C, Pappalardi MB, Zhang XP, Montes de Oca R, Penebre E, Duncan K, Boriack-Sjodin A, Le B, Majer C, McCabe MT, Carpenter C, Johnson N, Kruger RG, Barbash O (2018). Activation of the p53-MDM4 regulatory axis defines the anti-tumour response to PRMT5 inhibition through its role in regulating cellular splicing. Sci Rep 8(1): 9711. doi: 10.1038/s41598-018-28002-y

66. AbuHammad S, Cullinane C, Martin C, Bacolas Z, Ward T, Chen H, Slater A, Ardley K, Kirby L, Chan KT, Brajanovski N, Smith LK, Rao AD, Lelliott EJ, Kleinschmidt M, Vergara IA, Papenfuss AT, Lau P, Ghosh P, Haupt S, Haupt Y, Sanij E, Poortinga G, Pearson RB, Falk H, Curtis DJ, Stupple P, Devlin M, Street I, Davies MA, et al. (2019). Regulation of PRMT5-MDM4 axis is critical in the response to CDK4/6 inhibitors in melanoma. Proc Natl Acad Sci U S A 116(36): 17990-18000. doi: 10.1073/pnas.1901323116

67. Aggarwal P, Vaites LP, Kim JK, Mellert $H$, Gurung B, Nakagawa $H$ Herlyn M, Hua X, Rustgi AK, McMahon SB, Diehl JA (2010). Nuclear cyclin D1/CDK4 kinase regulates CUL4 expression and triggers neoplastic growth via activation of the PRMT5 methyltransferase. Cancer Cell 18(4): 329-340. doi: 10.1016/j.ccr.2010.08.012

68. Koh CM, Bezzi M, Low DH, Ang WX, Teo SX, Gay FP, Al-Haddawi M, Tan SY, Osato M, Sabo A, Amati B, Wee KB, Guccione E (2015). MYC regulates the core pre-mRNA splicing machinery as an essential step in lymphomagenesis. Nature 523(7558): 96-100. doi: 10.1038/nature14351

69. Hamard PJ, Santiago GE, Liu F, Karl DL, Martinez C, Man N, Mookhtiar AK, Duffort S, Greenblatt S, Verdun RE, Nimer SD (2018). PRMT5 Regulates DNA Repair by Controlling the Alternative Splicing of Histone-Modifying Enzymes. Cell Rep 24(10): 2643-2657. doi: 10.1016/j.celrep.2018.08.002

70. Yang J, Valineva T, Hong J, Bu T, Yao Z, Jensen ON, Frilander MJ, Silvennoinen $O$ (2007). Transcriptional co-activator protein p100 interacts with snRNP proteins and facilitates the assembly of the spliceosome. Nucleic Acids Res 35(13): 4485-4494. doi: 10.1093/nar/gkm470

71. Roworth AP, Carr SM, Liu G, Barczak W, Miller RL, Munro S, Kanapin A, Samsonova A, La Thangue NB (2019). Arginine methylation expands the regulatory mechanisms and extends the genomic landscape under E2F control. Sci Adv 5(6): eaaw4640. doi: 10.1126/sciadv.aaw4640

72. Braun CJ, Stanciu M, Boutz PL, Patterson JC, Calligaris D, Higuchi F, Neupane R, Fenoglio S, Cahill DP, Wakimoto H, Agar NYR, Yaffe MB, Sharp PA, Hemann MT, Lees JA (2017). Coordinated Splicing of Regulatory Detained Introns within Oncogenic Transcripts Creates an Exploitable Vulnerability in Malignant Glioma. Cancer Cell 32(4): 411426 e411. doi: 10.1016/j.ccell.2017.08.018

73. Eram MS, Shen Y, Szewczyk M, Wu H, Senisterra G, Li F, Butler KV, Kaniskan HU, Speed BA, Dela Sena C, Dong A, Zeng H, Schapira M, Brown PJ, Arrowsmith CH, Barsyte-Lovejoy D, Liu J, Vedadi M, Jin J (2016). A Potent, Selective, and Cell-Active Inhibitor of Human Type I Protein Arginine Methyltransferases. ACS Chem Biol 11(3): 772-781. doi: 10.1021/acschembio.5b00839

74. Duncan KW, Rioux N, Boriack-Sjodin PA, Munchhof MJ, Reiter LA, Majer CR, Jin L, Johnston LD, Chan-Penebre E, Kuplast KG, Porter Scott M, Pollock RM, Waters NJ, Smith JJ, Moyer MP, Copeland RA, Chesworth R (2016). Structure and Property Guided Design in the Identification of PRMT5 Tool Compound EPZ015666. ACS Med Chem Lett 7(2): 162-166. doi: 10.1021/acsmedchemlett.5b00380

75. Fedoriw A, Rajapurkar SR, O'Brien S, Gerhart SV, Mitchell LH, Adams ND, Rioux N, Lingaraj T, Ribich SA, Pappalardi MB, Shah N, Laraio J, Liu Y, Butticello M, Carpenter CL, Creasy C, Korenchuk S, McCabe MT, McHugh CF, Nagarajan R, Wagner C, Zappacosta F,
Annan R, Concha NO, Thomas RA, Hart TK, Smith JJ, Copeland RA, Moyer MP, Campbell J, et al. (2019). Anti-tumor Activity of the Type I PRMT Inhibitor, GSK3368715, Synergizes with PRMT5 Inhibition through MTAP Loss. Cancer Cell 36(1): 100-114 e125. doi: 10.1016/j.ccell.2019.05.014

76. Ren J, Wang $Y$, Liang $Y$, Zhang $Y$, Bao $S$, Xu Z (2010). Methylation of ribosomal protein $\mathrm{S} 10$ by protein-arginine methyltransferase 5 regulates ribosome biogenesis. J Biol Chem 285(17): 12695-12705. doi: 10.1074/jbc.M110.103911

77. Gao G, Dhar S, Bedford MT (2017). PRMT5 regulates IRESdependent translation via methylation of hnRNP A1. Nucleic Acids Res 45(8): 4359-4369. doi: 10.1093/nar/gkw1367

78. Gu Z, Gao S, Zhang F, Wang Z, Ma W, Davis RE, Wang Z (2012). Protein arginine methyltransferase 5 is essential for growth of lung cancer cells. Biochem J 446(2): 235-241. doi: 10.1042/BJ20120768

79. Sheng $X$, Wang $Z$ (2016). Protein arginine methyltransferase 5 regulates multiple signaling pathways to promote lung cancer cell proliferation. BMC Cancer 16: 567. doi: 10.1186/s12885-016-2632-3

80. Hsu JM, Chen CT, Chou CK, Kuo HP, Li LY, Lin CY, Lee HJ, Wang YN, Liu M, Liao HW, Shi B, Lai CC, Bedford MT, Tsai CH, Hung MC (2011). Crosstalk between $\operatorname{Arg} 1175$ methylation and Tyr 1173 phosphorylation negatively modulates EGFR-mediated ERK activation. Nat Cell Biol 13(2): 174-181. doi: 10.1038/ncb2158

81. Andreu-Perez P, Esteve-Puig R, de Torre-Minguela C, LopezFauqued M, Bech-Serra JJ, Tenbaum S, Garcia-Trevijano ER, Canals F, Merlino G, Avila MA, Recio JA (2011). Protein arginine methyltransferase 5 regulates ERK1/2 signal transduction amplitude and cell fate through CRAF. Sci Signal 4(190): ra58. doi: 10.1126/scisignal.2001936

82. Calabretta S, Vogel G, Yu Z, Choquet K, Darbelli L, Nicholson TB, Kleinman CL, Richard S (2018). Loss of PRMT5 Promotes PDGFRalpha Degradation during Oligodendrocyte Differentiation and Myelination. Dev Cell 46(4): 426-440 e425. doi: 10.1016/j.devcel.2018.06.025

83. Tanaka H, Hoshikawa Y, Oh-hara T, Koike S, Naito M, Noda T, Arai H, Tsuruo T, Fujita N (2009). PRMT5, a novel TRAIL receptor-binding protein, inhibits TRAIL-induced apoptosis via nuclear factor-kappaB activation. Mol Cancer Res 7(4): 557-569. doi: 10.1158/15417786.MCR-08-0197

84. Gulla A, Hideshima T, Bianchi G, Fulciniti M, Kemal Samur M, Qi J, Tai YT, Harada T, Morelli E, Amodio N, Carrasco R, Tagliaferri P, Munshi NC, Tassone P, Anderson KC (2018). Protein arginine methyltransferase 5 has prognostic relevance and is a druggable target in multiple myeloma. Leukemia 32(4): 996-1002. doi: 10.1038/leu.2017.334

85. Gaillard H, Garcia-Muse T, Aguilera A (2015). Replication stress and cancer. Nat Rev Cancer 15(5): 276-289. doi: 10.1038/nrc3916

86. O'Connor MJ (2015). Targeting the DNA Damage Response in Cancer. Mol Cell 60(4): 547-560. doi: 10.1016/j.molcel.2015.10.040

87. Lans H, Hoeijmakers JHJ, Vermeulen W, Marteijn JA (2019). The DNA damage response to transcription stress. Nat Rev Mol Cell Biol 20(12): 766-784. doi: 10.1038/s41580-019-0169-4

88. Du C, Hansen LJ, Singh SX, Wang F, Sun R, Moure CJ, Roso K, Greer PK, Yan H, He Y (2019). A PRMT5-RNF168-SMURF2 Axis Controls H2AX Proteostasis. Cell Rep 28(12): 3199-3211 e3195. doi: 10.1016/j.celrep.2019.08.031

89. Guo Z, Zheng L, Xu H, Dai H, Zhou M, Pascua MR, Chen QM, Shen B (2010). Methylation of FEN1 suppresses nearby phosphorylation and facilitates PCNA binding. Nat Chem Biol 6(10): 766-773. doi: 10.1038/nchembio. 422 
90. He W, Ma X, Yang X, Zhao Y, Qiu J, Hang H (2011). A role for the arginine methylation of Rad9 in checkpoint control and cellular sensitivity to DNA damage. Nucleic Acids Res 39(11): 4719-4727. doi: 10.1093/nar/gkq1264

91. Clarke TL, Sanchez-Bailon MP, Chiang K, Reynolds JJ, Herrero-Ruiz J, Bandeiras TM, Matias PM, Maslen SL, Skehel JM, Stewart GS, Davies CC (2017). PRMT5-Dependent Methylation of the TIP60 Coactivator RUVBL1 Is a Key Regulator of Homologous Recombination. Mol Cell 65(5): 900-916 e907. doi: 10.1016/j.molcel.2017.01.019

92. Rehman I, Basu SM, Das SK, Bhattacharjee S, Ghosh A, Pommier Y, Das BB (2018). PRMT5-mediated arginine methylation of TDP1 for the repair of topoisomerase I covalent complexes. Nucleic Acids Res 46(11): 5601-5617. doi: 10.1093/nar/gky291

93. Kim H, Kim H, Feng Y, Li Y, Tamiya H, Tocci S, Ronai ZA (2020). PRMT5 control of CGAS/STING and NLRC5 pathways defines melanoma response to antitumor immunity. Sci Translat Med 12(551):eaaz5683. doi: 10.1126/scitranslmed.aaz5683

94. Liu F, Cheng G, Hamard PJ, Greenblatt S, Wang L, Man N, Perna F, Xu H, Tadi M, Luciani L, Nimer SD (2015). Arginine methyltransferase PRMT5 is essential for sustaining normal adult hematopoiesis. J Clin Invest 125(9): 3532-3544. doi: 10.1172/JCI81749

95. Geoghegan V, Guo A, Trudgian D, Thomas B, Acuto O (2015). Comprehensive identification of arginine methylation in primary $T$ cells reveals regulatory roles in cell signalling. Nat Commun 6: 6758 . doi: $10.1038 /$ ncomms 7758

96. Webb LM, Narvaez Miranda J, Amici SA, Sengupta S, Nagy G, Guerau-de-Arellano M (2019). NF-kappaB/mTOR/MYC Axis Drives PRMT5 Protein Induction After T Cell Activation via Transcriptional and Non-transcriptional Mechanisms. Front Immunol 10: 524. doi: 10.3389/fimmu.2019.00524

97. Richard S, Morel M, Cleroux P (2005). Arginine methylation regulates IL-2 gene expression: a role for protein arginine methyltransferase 5 (PRMT5). Biochem J 388(Pt 1): 379-386. doi: 10.1042/BJ20040373

98. Webb LM, Amici SA, Jablonski KA, Savardekar H, Panfil AR, Li L, Zhou W, Peine K, Karkhanis V, Bachelder EM, Ainslie KM, Green PL, Li C, Baiocchi RA, Guerau-de-Arellano M (2017). PRMT5-Selective Inhibitors Suppress Inflammatory T Cell Responses and Experimental Autoimmune Encephalomyelitis. J Immunol 198(4): 1439-1451. doi: 10.4049/jimmunol.1601702

99. Inoue M, Okamoto K, Terashima A, Nitta T, Muro R, Negishi-Koga T, Kitamura T, Nakashima T, Takayanagi H (2018). Arginine methylation controls the strength of gammac-family cytokine signaling in T cell maintenance. Nat Immunol 19(11): 1265-1276. doi: $10.1038 /$ s41590-018-0222-z

100. Tanaka Y, Nagai Y, Okumura M, Greene MI, Kambayashi T (2020). PRMT5 Is Required for T Cell Survival and Proliferation by Maintaining Cytokine Signaling. Front Immunol 11: 621. doi: 10.3389/fimmu.2020.00621

101. Webb LM, Sengupta S, Edell C, Piedra-Quintero ZL, Amici SA, Miranda JN, Bevins M, Kennemer A, Laliotis G, Tsichlis PN, Guerau-deArellano M (2020). Protein arginine methyltransferase 5 promotes cholesterol biosynthesis-mediated Th17 responses and autoimmunity. J Clin Invest 130(4): 1683-1698. doi: 10.1172/JCI131254

102. Snyder KJ, Zitzer NC, Gao Y, Choe HK, Sell NE, Neidemire-Colley L, Ignaci A, Kale C, Devine RD, Abad MG, Pietrzak M, Wang M, Lin H, Zhang YW, Behbehani GK, Jackman JE, Garzon R, Vaddi K, Baiocchi RA, Ranganathan $P$ (2020). PRMT5 regulates $T$ cell interferon response and is a target for acute graft-versus-host disease. JCI Insight 5(8): e131099. doi: 10.1172/jci.insight.131099
103. Nagai $Y$, Ji MQ, Zhu F, Xiao Y, Tanaka Y, Kambayashi T, Fujimoto $S$, Goldberg MM, Zhang H, Li B, Ohtani T, Greene MI (2019). PRMT5 Associates With the FOXP3 Homomer and When Disabled Enhances Targeted p185(erbB2/neu) Tumor Immunotherapy. Front Immunol 10:174. doi: 10.3389/fimmu.2019.00174

104. Kagoya Y, Saijo H, Matsunaga Y, Guo T, Saso K, Anczurowski M, Wang $\mathrm{CH}$, Sugata $\mathrm{K}$, Murata $\mathrm{K}$, Butler $\mathrm{MO}$, Arrowsmith $\mathrm{CH}$, Hirano N (2019). Arginine methylation of FOXP3 is crucial for the suppressive function of regulatory $T$ cells. J Autoimmun 97: 10-21. doi: 10.1016/j.jaut.2018.09.011

105. Zhang HT, Zhang D, Zha ZG, Hu CD (2014). Transcriptional activation of PRMT5 by NF-Y is required for cell growth and negatively regulated by the $\mathrm{PKC} / \mathrm{c}$-Fos signaling in prostate cancer cells. Biochim Biophys Acta 1839(11): 1330-1340. doi: 10.1016/j.bbagrm.2014.09.015

106. Zhu F, Guo H, Bates PD, Zhang S, Zhang H, Nomie KJ, Li Y, Lu L, Seibold KR, Wang F, Rumball I, Cameron H, Hoang NM, Yang DT, Xu W, Zhang L, Wang M, Capitini CM, Rui L (2019). PRMT5 is upregulated by B-cell receptor signaling and forms a positive-feedback loop with PI3K/AKT in lymphoma cells. Leukemia 33(12): 2898-2911. doi: 10.1038/s41375-019-0489-6

107. Serio J, Ropa J, Chen W, Mysliwski M, Saha N, Chen L, Wang J, Miao H, Cierpicki T, Grembecka J, Muntean AG (2018). The PAF complex regulation of Prmt5 facilitates the progression and maintenance of MLL fusion leukemia. Oncogene 37(4): 450-460. doi: 10.1038/onc. 2017.337

108. Pal S, Baiocchi RA, Byrd JC, Grever MR, Jacob ST, Sif S (2007). Low levels of miR-92b/96 induce PRMT5 translation and H3R8/H4R3 methylation in mantle cell lymphoma. EMBO J 26(15): 3558-3569. doi: 10.1038/sj.emboj.7601794

109. Alinari L, Mahasenan KV, Yan F, Karkhanis V, Chung JH, Smith EM, Quinion C, Smith PL, Kim L, Patton JT, Lapalombella R, Yu B, Wu Y, Roy S, De Leo A, Pileri S, Agostinelli C, Ayers L, Bradner JE, Chen-Kiang S, Elemento O, Motiwala T, Majumder S, Byrd JC, Jacob S, Sif S, Li C, Baiocchi RA (2015). Selective inhibition of protein arginine methyltransferase 5 blocks initiation and maintenance of B-cell transformation. Blood 125(16): 2530-2543. doi: 10.1182/blood-201412-619783

110. Wu Z, Lin Y (2019). Long noncoding RNA LINC00515 promotes cell proliferation and inhibits apoptosis by sponging miR-16 and activating PRMT5 expression in human glioma. Onco Targets Ther 12: 25952604. doi: 10.2147/OTT.S198087

111. Sun CM, Zhang GM, Qian HN, Cheng SJ, Wang M, Liu M, Li D (2019). MiR-1266 suppresses the growth and metastasis of prostate cancer via targeting PRMT5. Eur Rev Med Pharmacol Sci 23(15): 64366444. doi: 10.26355/eurrev_201908_18525

112. Guo JQ, Yang ZJ, Wang S, Wu ZZ, Yin LL, Wang DC (2020). LncRNA SNHG16 functions as an oncogene by sponging miR-200a-3p in pancreatic cancer. Eur Rev Med Pharmacol Sci 24(4): 1718-1724. doi: 10.26355/eurrev_202002_20347

113. Zhang HT, Zeng LF, He QY, Tao WA, Zha ZG, Hu CD (2016). The E3 ubiquitin ligase CHIP mediates ubiquitination and proteasomal degradation of PRMT5. Biochim Biophys Acta 1863(2): 335-346. doi: 10.1016/j.bbamcr.2015.12.001

114. Li Z, Zhang J, Liu X, Li S, Wang Q, Di C, Hu Z, Yu T, Ding J, Li J, Yao M, Fan J, Huang S, Gao Q, Zhao Y, He X (2018). The LINC01138 drives malignancies via activating arginine methyltransferase 5 in hepatocellular carcinoma. Nat Commun 9(1): 1572 . doi: 10.1038/s41467-018-04006-0

115. Liu F, Zhao X, Perna F, Wang L, Koppikar P, Abdel-Wahab O, Harr MW, Levine RL, Xu H, Tefferi A, Deblasio A, Hatlen M, Menendez S, Nimer SD (2011). JAK2V617F-mediated phosphorylation of PRMT5 
downregulates its methyltransferase activity and promotes myeloproliferation. Cancer Cell 19(2): 283-294. doi: 10.1016/j.ccr.2010.12.020

116. Espejo AB, Gao G, Black K, Gayatri S, Veland N, Kim J, Chen T, Sudol M, Walker C, Bedford MT (2017). PRMT5 C-terminal Phosphorylation Modulates a 14-3-3/PDZ Interaction Switch. J Biol Chem 292(6): 2255-2265. doi: 10.1074/jbc.M116.760330

117. Sipos A, Ivan J, Becsi B, Darula Z, Tamas I, Horvath D, Medzihradszky KF, Erdodi F, Lontay B (2017). Myosin phosphatase and RhoA-activated kinase modulate arginine methylation by the regulation of protein arginine methyltransferase 5 in hepatocellular carcinoma cells. Sci Rep 7: 40590. doi: 10.1038/srep40590

118. Lattouf $H$, Kassem L, Jacquemetton J, Choucair A, Poulard C, Tredan O, Corbo L, Diab-Assaf M, Hussein N, Treilleux I, Le Romancer M (2019). LKB1 regulates PRMT5 activity in breast cancer. Int J Cancer 144(3): 595-606. doi: 10.1002/ijc.31909

119. Nie $M$, Wang $Y$, Guo $C$, Li $X$, Wang $Y$, Deng $Y$, Yao B, Gui T, Ma C, Liu M, Wang P, Wang R, Tan R, Fang M, Chen B, He Y, Huang DCS, Ju J, Zhao $Q$ (2018). CARM1-mediated methylation of protein arginine methyltransferase 5 represses human gamma-globin gene expression in erythroleukemia cells. J Biol Chem 293(45): 17454-17463. doi: 10.1074/jbc.RA118.004028

120. Qi H, Shi X, Yu M, Liu B, Liu M, Song S, Chen S, Zou J, Zhu WG, Luo $\mathrm{J}$ (2018). Sirtuin 7-mediated deacetylation of WD repeat domain 77 (WDR77) suppresses cancer cell growth by reducing WDR77/PRMT5 transmethylase complex activity. J Biol Chem 293(46): 17769-17779. doi: 10.1074/jbc.RA118.003629

121. Lacroix M, El Messaoudi S, Rodier G, Le Cam A, Sardet C, Fabbrizio $E$ (2008). The histone-binding protein COPR5 is required for nuclear functions of the protein arginine methyltransferase PRMT5. EMBO Rep 9(5): 452-458. doi: 10.1038/embor.2008.45

122. Azzouz TN, Pillai RS, Dapp C, Chari A, Meister G, Kambach C, Fischer U, Schumperli D (2005). Toward an assembly line for U7 SnRNPs: interactions of U7-specific Lsm proteins with PRMT5 and SMN complexes. J Biol Chem 280(41): 34435-34440. doi: 10.1074/jbc.M505077200

123. Pesiridis GS, Diamond E, Van Duyne GD (2009). Role of pICLn in methylation of Sm proteins by PRMT5. J Biol Chem 284(32): 2134721359. doi: 10.1074/jbc.M109.015578

124. Guderian G, Peter C, Wiesner J, Sickmann A, Schulze-Osthoff K, Fischer U, Grimmler M (2011). RioK1, a new interactor of protein arginine methyltransferase 5 (PRMT5), competes with plCln for binding and modulates PRMT5 complex composition and substrate specificity. J Biol Chem 286(3): 1976-1986. doi: 10.1074/jbc.M110.148486

125. Kryukov GV, Wilson FH, Ruth JR, Paulk J, Tsherniak A, Marlow SE, Vazquez F, Weir BA, Fitzgerald ME, Tanaka M, Bielski CM, Scott JM, Dennis C, Cowley GS, Boehm JS, Root DE, Golub TR, Clish CB, Bradner JE, Hahn WC, Garraway LA (2016). MTAP deletion confers enhanced dependency on the PRMT5 arginine methyltransferase in cancer cells. Science 351(6278): 1214-1218. doi: 10.1126/science.aad5214

126. Mavrakis KJ, McDonald ER, 3rd, Schlabach MR, Billy E, Hoffman GR, deWeck A, Ruddy DA, Venkatesan K, Yu J, McAllister G, Stump M, deBeaumont R, Ho S, Yue $Y$, Liu $Y$, Yan-Neale $Y$, Yang G, Lin F, Yin $H$, Gao H, Kipp DR, Zhao S, McNamara JT, Sprague ER, Zheng B, Lin Y, Cho YS, Gu J, Crawford K, Ciccone D, et al. (2016). Disordered methionine metabolism in MTAP/CDKN2A-deleted cancers leads to dependence on PRMT5. Science 351(6278): 1208-1213. doi: 10.1126/science.aad5944

127. Marjon K, Cameron MJ, Quang P, Clasquin MF, Mandley E, Kunii K, McVay M, Choe S, Kernytsky A, Gross S, Konteatis Z, Murtie J, Blake ML, Travins J, Dorsch M, Biller SA, Marks KM (2016). MTAP Deletions in Cancer Create Vulnerability to Targeting of the MAT2A/PRMT5/RIOK1 Axis. Cell Rep 15(3): 574-587. doi: 10.1016/j.celrep.2016.03.043

128. Gao G, Zhang L, Villarreal OD, He W, Su D, Bedford E, Moh P, Shen J, Shi X, Bedford MT, Xu H (2019). PRMT1 loss sensitizes cells to PRMT5 inhibition. Nucleic Acids Res 47(10): 5038-5048. doi: 10.1093/nar/gkz200

129. Ancelin K, Lange UC, Hajkova P, Schneider R, Bannister AJ, Kouzarides T, Surani MA (2006). Blimp1 associates with Prmt5 and directs histone arginine methylation in mouse germ cells. Nat Cell Biol 8(6): 623-630. doi: 10.1038/ncb1413

130. Tan DQ, Li Y, Yang C, Li J, Tan SH, Chin DWL, Nakamura-Ishizu A, Yang H, Suda T (2019). PRMT5 Modulates Splicing for Genome Integrity and Preserves Proteostasis of Hematopoietic Stem Cells. Cell Rep 26(9): 2316-2328 e2316. doi: 10.1016/j.celrep.2019.02.001

131. Jin Y, Zhou J, Xu F, Jin B, Cui L, Wang Y, Du X, Li J, Li P, Ren R, Pan J (2016). Targeting methyltransferase PRMT5 eliminates leukemia stem cells in chronic myelogenous leukemia. J Clin Invest 126(10): 39613980. doi: $10.1172 / \mathrm{JCl} 85239$

132. Secker KA, Keppeler H, Duerr-Stoerzer S, Schmid H, Schneidawind D, Hentrich T, Schulze-Hentrich JM, Mankel B, Fend F, Schneidawind C (2019). Inhibition of DOT1L and PRMT5 promote synergistic antitumor activity in a human MLL leukemia model induced by CRISPR/Cas9. Oncogene 38(46): 7181-7195. doi: 10.1038/s41388-0190937-9

133. Chan-Penebre E, Kuplast KG, Majer CR, Boriack-Sjodin PA, Wigle TJ, Johnston LD, Rioux N, Munchhof MJ, Jin L, Jacques SL, West KA, Lingaraj T, Stickland K, Ribich SA, Raimondi A, Scott MP, Waters NJ, Pollock RM, Smith JJ, Barbash O, Pappalardi M, Ho TF, Nurse K, Oza KP, Gallagher KT, Kruger R, Moyer MP, Copeland RA, Chesworth R, Duncan KW (2015). A selective inhibitor of PRMT5 with in vivo and in vitro potency in MCL models. Nat Chem Biol 11(6): 432-437. doi: 10.1038/nchembio. 1810

134. Chen H, Lorton B, Gupta V, Shechter D (2017). A TGFbeta-PRMT5MEP50 axis regulates cancer cell invasion through histone $\mathrm{H} 3$ and $\mathrm{H} 4$ arginine methylation coupled transcriptional activation and repression. Oncogene 36(3): 373-386. doi: 10.1038/onc.2016.205

135. Rengasamy $M$, Zhang $F$, Vashisht $A$, Song WM, Aguilo F, Sun $Y$, Li $S$, Zhang W, Zhang B, Wohlschlegel JA, Walsh MJ (2017). The PRMT5/WDR77 complex regulates alternative splicing through ZNF326 in breast cancer. Nucleic Acids Res 45(19): 11106-11120. doi: 10.1093/nar/gkx727

136. Powers MA, Fay MM, Factor RE, Welm AL, Ullman KS (2011). Protein arginine methyltransferase 5 accelerates tumor growth by arginine methylation of the tumor suppressor programmed cell death 4. Cancer Res 71(16): 5579-5587. doi: 10.1158/0008-5472.CAN-110458

137. Fay MM, Clegg JM, Uchida KA, Powers MA, Ullman KS (2014). Enhanced arginine methylation of programmed cell death 4 protein during nutrient deprivation promotes tumor cell viability. J Biol Chem 289(25): 17541-17552. doi: 10.1074/jbc.M113.541300 